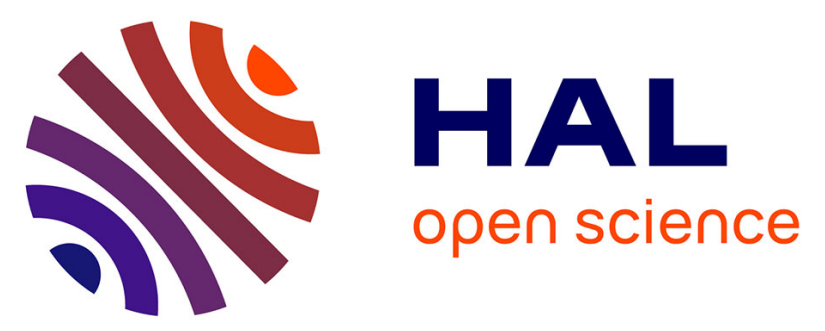

\title{
Highly active and stable Ni/SBA-15 catalysts prepared by a "two solvents" method for dry reforming of methane
}

M.N. Kaydouh, N El Hassan, A Davidson, S Casale, H El Zakhem, P Massiani

\section{- To cite this version:}

M.N. Kaydouh, N El Hassan, A Davidson, S Casale, H El Zakhem, et al.. Highly active and stable Ni/SBA-15 catalysts prepared by a "two solvents" method for dry reforming of methane. Microporous and Mesoporous Materials, 2016, 220, pp.99-109. 10.1016/j.micromeso.2015.08.034 . hal-01195558

\section{HAL Id: hal-01195558 \\ https://hal.sorbonne-universite.fr/hal-01195558}

Submitted on 8 Sep 2015

HAL is a multi-disciplinary open access archive for the deposit and dissemination of scientific research documents, whether they are published or not. The documents may come from teaching and research institutions in France or abroad, or from public or private research centers.
L'archive ouverte pluridisciplinaire HAL, est destinée au dépôt et à la diffusion de documents scientifiques de niveau recherche, publiés ou non, émanant des établissements d'enseignement et de recherche français ou étrangers, des laboratoires publics ou privés. 


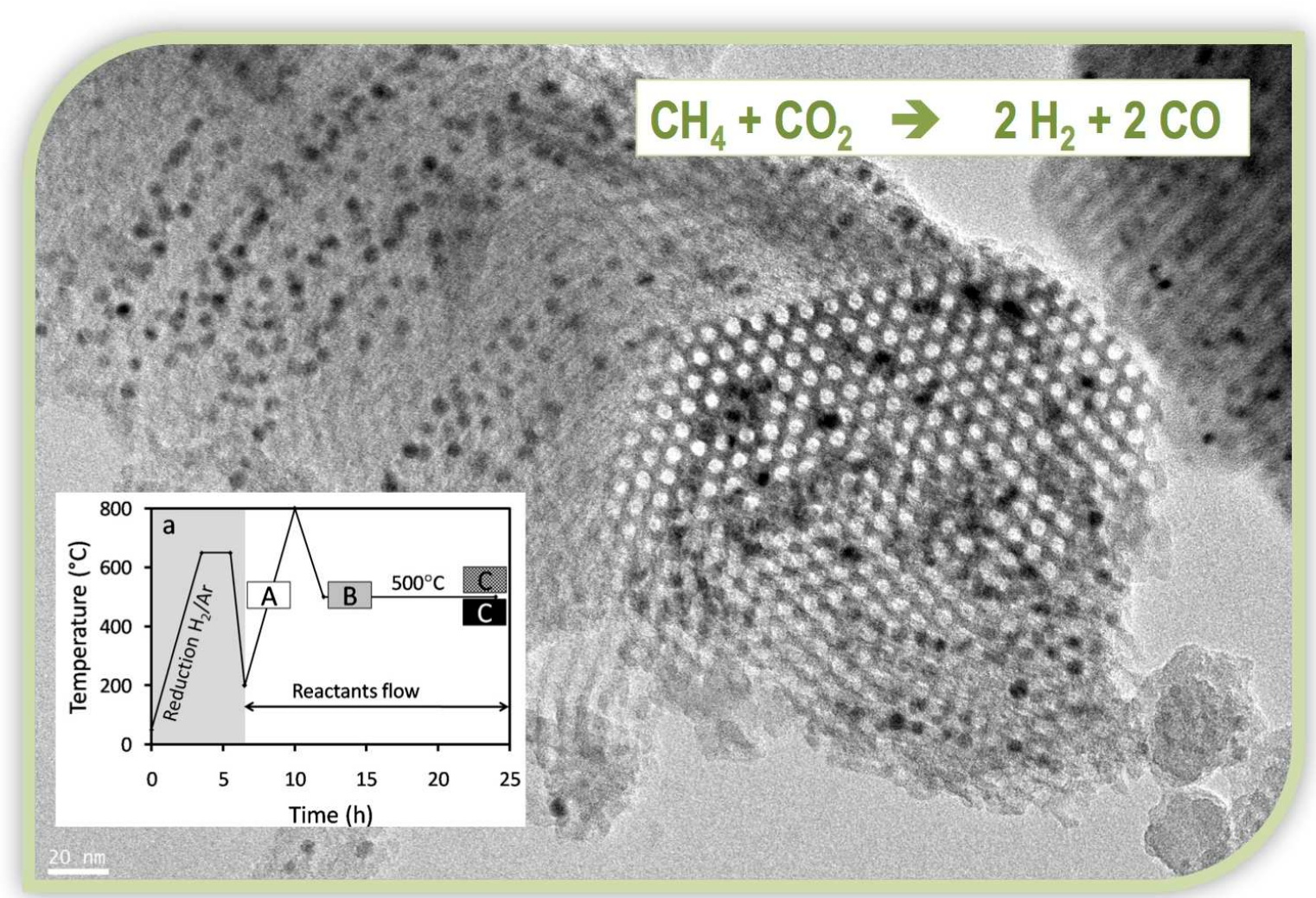




\title{
Highly active and stable Ni/SBA-15 catalysts prepared by a "two solvents" method for dry reforming of methane
}

\author{
M.N. Kaydouh ${ }^{\text {a,b }}$, N. El Hassan ${ }^{a^{*}}$, A. Davidson ${ }^{b}$, S. Casale $^{b}$, H. El Zakhem ${ }^{a}$, and P. Massiani ${ }^{b, c^{*}}$
}

${ }^{a}$ Department of Chemical Engineering, Faculty of Engineering, University of Balamand, POBox 100,Tripoli, Lebanon, nissrine.hassan@balamand.edu.lb

${ }^{b}$ Sorbonne Universités, UPMC Université Paris 06, Laboratoire de Réactivité de Surface, 4 place Jussieu, 75005 Paris, France, pascale.massiani@upmc.fr

${ }^{c}$ CNRS UMR 7197, UPMC, Laboratoire de Réactivité de Surface, 4 place Jussieu, 75005 Paris, France

\begin{abstract}
Two series of $\mathrm{Ni}$ (2.5 to $7.5 \mathrm{wt} \%)$ and Ce (6 wt $\%$ ) containing SBA-15 catalysts were prepared and tested in dry reforming of methane, a promising route for the production of syngas. Both $\mathrm{Ni}$ and $\mathrm{Ce}$ species were introduced in the organized mesoporous silica support in the form of nitrate salts using the "two solvents" procedure that is known to favor metal dispersion inside the porosity. Samples characterizations by $\mathrm{N}_{2}$ sorption, SAXS, XRD, SEM and TEM indicate good preservation of the porosities after $\mathrm{Ni}$ deposition and calcination as well as formation of $\mathrm{NiO}$ nanoparticles entrapped in the porous channels. In the cerium-enriched samples, the $\mathrm{CeO}_{2}$ nanoparticles are also highly dispersed. After reduction, all the catalysts show high activity and selectivity towards $\mathrm{H}_{2}$ and $\mathrm{CO}$ at atmospheric pressure with full $\mathrm{CH}_{4}$ conversion below $650^{\circ} \mathrm{C}$. In these conditions, there is no significant promotional effect by ceria. Moreover, prolonged tests performed at $500^{\circ} \mathrm{C}$ for 12 hours reveal a high stability of the catalysts. The absence of deactivation throughout the catalytic run at this temperature agrees with the low carbon amount detected after test and with the limited sintering of the Ni nanoparticles in the used catalysts. The positive effect of the SBA-15 mesoporous channels towards stabilization of the supported particles is discussed.
\end{abstract}

Keywords: methane reforming, mesoporous SBA-15, nickel nanoparticles, catalytic stability, dispersion

\section{Introduction}

Fischer-Tropsch Synthesis (FTS) is an important process for the production of liquid hydrocarbons from syngas. The latter is a gaseous mixture primarily composed of $\mathrm{CO}$ and $\mathrm{H}_{2}$ in a ratio that varies depending on its method of production. The three main processes for syngas production are steam reforming of methane (reaction of $\mathrm{H}_{2} \mathrm{O}$ with $\mathrm{CH}_{4}$ ), $\mathrm{CO}_{2}$ reforming of methane (reaction of $\mathrm{CO}_{2}$ with $\mathrm{CH}_{4}$ ) and partial oxidation of biomass, methane, coal, or petroleum naphtha [1]. Among these reactions, $\mathrm{CO}_{2}$ reforming of methane has the strong advantage of producing a clean $\mathrm{CO}$ and $\mathrm{H}_{2}$ mixture in an equimolar ratio (1:1) best suited for subsequent FTS reaction [2-4]. The obtained $\mathrm{H}_{2} / \mathrm{CO}$ ratio is on the contrary near 3 (i.e. too high for FTS) when syngas is produced from steam reforming of methane. It is around 2 with direct oxidation of methane but the process is then highly exothermic, being thus risky and insecure due to the formation of hot spots, particularly at high space velocities, leading to difficulties in process control. Based on these considerations, dry reforming of methane (DRM) arises as one of the 
most promising methods for syngas production. Moreover, an important advantage is that syngas is then produced from the consumption of methane and carbon dioxide that are two gases with strong greenhouse effect, thus offering an additional environmental benefit.

In the process of dry reforming of methane by carbon dioxide, the main reaction $\left(\mathrm{CH}_{4}+\mathrm{CO}_{2} \rightarrow\right.$ $2 \mathrm{H}_{2}+2 \mathrm{CO}$ ) occurs in the gas phase. Secondary reactions can also take place especially reverse water gas shift (RWGS, $\mathrm{CO}_{2}+\mathrm{H}_{2} \rightarrow \mathrm{CO}+\mathrm{H}_{2} \mathrm{O}$ ), methane decomposition $\left(\mathrm{CH}_{4} \rightarrow 2 \mathrm{H}_{2}+\mathrm{C}\right.$ ), and $\mathrm{CO}$ disproportionation known as Boudouard reaction $\left(2 \mathrm{CO} \rightarrow \mathrm{CO}_{2}+\mathrm{C}\right)$. The last two reactions produce carbon that can contribute to catalyst deactivation by forming carbonaceous deposits on the inner and/or outer catalytic surfaces [5]. Besides, both Boudouard and RWGS reactions occur at low temperatures while DRM (main reaction) and methane decomposition require high temperatures. Therefore, a reasonable goal for reaching more efficient and energetically less demanding reforming processes is to design heterogeneous catalysts able to perform the reaction at moderate temperatures where carbon formation is inhibited.

As recently reviewed [6], supported catalysts containing noble metals such as $\mathrm{Rh}, \mathrm{Ru}, \mathrm{Pt}$ or $\mathrm{Pd}$ are active catalysts for DRM. They are also stable at the high temperatures $\left(>600^{\circ} \mathrm{C}\right)$ classically needed to achieve high conversions [7,8]. However, due to economic and environmental constraints, the substitution of noble metals by transition ones, especially nickel [9-16], is nowadays attractive. In this context, Hou et al. reported that nickel nanoparticles well-dispersed on alumina can provide high $\mathrm{CH}_{4}$ and $\mathrm{CO}_{2}$ conversions close to those obtained on $\mathrm{Rh}$ based catalysts [11]. Similarly, Jozwiak et al. found good and comparable performances towards DRM using catalysts with either $\mathrm{Ni}, \mathrm{Rh}$ or bimetallic $\mathrm{Ni}-\mathrm{Rh}$ nanoparticles supported on $\mathrm{SiO}_{2}$ [12]. However, the Ni containing catalysts suffered from heavy coke deposition [11-14]. Therefore, increasing coke resistance appears as a key parameter to develop new efficient Ni-based catalysts for DRM. Ni particles' sintering during activation and reaction is also an important drawback that should be avoided.

In a recent study, Gong et al. succeeded in stabilizing nickel particles in phyllosilicate nanotubes and obtained catalysts with excellent DRM performances and coke resistance [17]. Similarly, Ma et al. found that nickel nanoparticles located inside carbon nanotubes are more reducible and resistant to sintering as well as catalytically more active and stable than those loaded outside the nanotubes [18]. Besides, various authors reported a promoting effect of ceria in these catalysts due to (i) higher availability of oxygen atoms that inhibit coke formation and (ii) enhancement of the Ni nanoparticles dispersion and stability [19-23]. It was also proposed that the performances of ceria-doped mesoporous Ni/SBA-16 in DRM were increased through metal-support interactions [24].

In this context, the purpose of the present work was to prepare efficient and stable Ni/SBA- 15 catalysts with and without $\mathrm{CeO}_{2}$. The organized SBA-15 mesoporous silica was selected as support because of its ordered channel system with high internal surface area and high pore volume that gives high capability to disperse and stabilize oxide and metal nanoparticles. This choice was also established from recent results reporting promising behaviors of Ni based SBA15 catalysts in DRM $[20,21,25]$. In these works, however, the catalysts were prepared by classical 
incipient wetness impregnation [20,21] and nickel depositions both inside and outside the pores were observed. Therefore, our purpose in this work was to prepare improved Ni(Ce)/SBA-15 catalysts with active $\mathrm{Ni}$ (and $\mathrm{Ce}$ ) nanoparticles highly dispersed all over the support and predominantly (if not fully) located at the interior of the mesoporous channels. To this end, we used a "two solvents" method that consists in suspending the mesoporous silica in a hydrophobic solvent (e.g. hexane) before mixing it with the aqueous metal precursor solution. Indeed, it was shown that this facilitates the homogeneous penetration of the impregnating metal precursor solution inside the channels while simultaneously avoiding excessive local impregnation at the external surface of the silica grains [26-31]. As a result, higher deposition of the supported active phases inside the pores compared to classical impregnation is obtained, which should be strongly benefic to both the activity and stability of the catalysts during DRM reaction. The addition of ceria in some samples was carried out to check if the above mentioned promoting effect reported by various authors remains in our preparation conditions.

\section{Experimental part}

\subsection{Catalyst preparation}

The SBA-15 silica supports were synthesized according to a standard procedure adapted from the recipe described by Zhao et al. [32]. Thus, $8 \mathrm{~g}$ of P123 were dissolved in $252 \mathrm{~mL} \mathrm{HCl}(1.9 \mathrm{M})$ at $35^{\circ} \mathrm{C}$ for $24 \mathrm{~h}$ then $18.4 \mathrm{~mL}$ of TEOS were added drop by drop and the resulting solution was kept under heating at $35^{\circ} \mathrm{C}$ for another $24 \mathrm{~h}$. The syntheses were carried out without applying a condensation hydrothermal treatment. After recovery by filtration, the powders were calcined at $500^{\circ} \mathrm{C}$ (heating rate $2^{\circ} \mathrm{C} \cdot \mathrm{min}^{-1}$ ) for about 9 hours in a muffle furnace (Nabertherm, LE6/11) to eliminate the structuring organic agent and the $\mathrm{Cl}$ ions. In order to have sufficient amount of support, two silica batches were prepared (denoted SBA-15 1 and SBA-152), with close textural properties (see results section). For both preparations, we checked that the calcined mesoporous silica were almost chlorine free.

The deposition of the precursor nickel nitrate $\left(\mathrm{Ni}(\mathrm{NO})_{2} \cdot 6 \mathrm{H}_{2} \mathrm{O}\right)$ or cerium nitrate $\left(\mathrm{Ce}\left(\mathrm{NO}_{3}\right)_{3} \cdot 6 \mathrm{H}_{2} \mathrm{O}\right)$ salts (from Sigma-Aldrich) inside the pores of the SBA-15 supports was carried out using the "two solvents" procedure detailed elsewhere [26-28]: briefly, $1 \mathrm{~g}$ of support was suspended in 20 $\mathrm{mL}$ of $\mathrm{n}$-hexane for about $15 \mathrm{~min}$, then a volume of water set equal to the silica porous volume (as determined by $\mathrm{N}_{2}$ sorption) and containing the appropriate amount of metal salt precursor was added dropwise. Afterwards, the impregnated samples were left to dry overnight under air. The cerium content was identical in all Ce-containing catalysts $(6 \mathrm{wt} \%)$ while the concentration of nickel varied $(2.5,5.0$ or $7.5 \mathrm{wt} \%)$. For the Ce-containing samples, the Ce loading was carried out first, followed by calcination in air for 5 hours at $450^{\circ} \mathrm{C}$ (thin bed conditions, heating rate $0.5^{\circ} \mathrm{C} \cdot \mathrm{min}^{-1}$ ), then $\mathrm{Ni}$ addition and calcination were conducted as above. The obtained samples are designated $\mathrm{Ni}_{\mathrm{x}} / \mathrm{SBA}-15_{1}$ and $\mathrm{Ni}_{\mathrm{x}} \mathrm{Ce}_{6} / \mathrm{SBA}-15_{2}$, where $\mathrm{x}$ is the $\mathrm{Ni}$ wt $\%$. A $\mathrm{Ni}$ free sample $\left(\mathrm{Ni}_{0} / \mathrm{SBA}-15_{2}\right)$ was also prepared by submitting the SBA-15 mesoporous silica to the "two solvents" preparation (including calcination) but without adding nickel nitrate. Finally, a 
reference sample was similarly prepared $\left(\mathrm{Ni}_{5} / \mathrm{SiO}_{2}\right)$, Susing fumed silica (Sigma-Aldrich) as support.

\subsection{Characterization techniques}

The textural properties were determined from $\mathrm{N}_{2}$ adsorption-desorption isotherms recorded on an ASAP 2020 (Micromeritics) apparatus. Prior to experiments, the samples were degassed under vacuum for 2 hours at $250^{\circ} \mathrm{C}$. X-ray Diffraction (XRD) studies were carried out using a Brüker D8 diffractometer (Bragg-Brentano, Copper $\alpha=1.5418 \AA$ ). Coherent crystallographic domains were determined by standard analysis of FWHM (Full Width at Half Maximum) using the Scherrer equation applied with a Warren correction. The Small angle X-Ray scattering (SAXS) measurements were recorded on the SWING beamline of synchrotron SOLEIL using experimental conditions detailed elsewhere [33]. The morphologies of the silica grains and oxides/metal nanoparticles were determined by transmission electron microscopy (TEM) on a 2010 JEOL TEM microscope operating at $200 \mathrm{keV}$ (LaB6 gun) equipped with an energy dispersive spectroscopy (EDS) probe for local chemical analyses. The mean particle sizes were evaluated by counting at least 500 particles. Scanning election microscopy (SEM) micrographs were registered on a Hitachi SU-70 SEM-FEG that did not necessitate covering the sample with a carbon or gold conducting film previous to observations. The images were recorded in a mixed mode to obtain simultaneous information on the surface morphology of the grains $(70 \%$ of secondary electrons signal) and on the external Ni-based species, if present (30\% of retro-diffused signal).

\subsection{Catalytic tests}

The catalytic tests were conducted at atmospheric pressure in a continuous U-shaped fixed bed flow reactor in quartz. Either $20 \mathrm{mg}$ or $100 \mathrm{mg}$ of powder were loaded on a quartz wool plug. These two masses were selected to provide information on diffusion limitations. Prior to the catalytic reaction, each sample was thermally reduced in situ at $650^{\circ} \mathrm{C}$ for about 2 hours (heating rate $10^{\circ} \mathrm{C} \cdot \mathrm{min}^{-1}$ ) in a $5 \% \mathrm{H}_{2} / \mathrm{Ar}$ flow $\left(30 \mathrm{~mL} \cdot \mathrm{min}^{-1}\right.$ ). Before TCD detection (Autochem 2010 micromeritics instrument), the flow was passed in a cold trap (bath made of ice and $\mathrm{NaCl}$ ) to remove water and ensure detection of the sole reduction process ( $\mathrm{H}_{2}$ consumption). The temperature was next cooled down to $200^{\circ} \mathrm{C}$ and the gas was switched to an equimolar reactant mixture of $\mathrm{CH}_{4}$ and $\mathrm{CO}_{2}$ (total gas hourly space velocity of $52.8 \mathrm{~L} \cdot \mathrm{g}^{-1} \cdot \mathrm{h}^{-1}$ and $264 \mathrm{~L} \cdot \mathrm{g}^{-1} \cdot \mathrm{h}^{-1}$ for the 100 and $20 \mathrm{mg}$ loadings, respectively). Then, the temperature was increased from 200 to $800^{\circ} \mathrm{C}$ at a rate of $5^{\circ} \mathrm{C} \cdot \mathrm{min}^{-1}$ (light-off curves) and the reactants and products were regularly analyzed in a Micro-GC Inficon apparatus equipped with a Thermal Conductivity Detector (TCD) and two columns in parallel for the detection of $\mathrm{CH}_{4}, \mathrm{H}_{2}$ and $\mathrm{CO}$ (Molecular Sieve column) and of $\mathrm{CO}_{2}$ (plot U column). Finally, the temperature was decreased to $500^{\circ} \mathrm{C}$ in 30 minutes and maintained at this temperature for 12 hours to perform stability measurements. 


\subsection{Structure and porosity of the parent and calcined samples}

The textural properties of the prepared materials were analyzed by $\mathrm{N}_{2}$ sorption experiments. All parent SBA-15 supports and impregnated catalysts present a type IV isotherm with a H1 hysteresis loop typical of well-ordered porous materials with parallel mesopores (Fig. 1). However, the pore volumes and surface area vary with the sample (Table 1).

First, the lower adsorbed volumes in SBA-15 compared to SBA-152, especially at P/ $\mathrm{P}_{0}$ below 0.035 (Fig. 1a and 1c respectively), indicate a smaller content of micropores in this silica sample. This can be due firstly to the absence of hydrothermal condensation step during the synthesis of these parent samples, which makes them more sensitive to structural shrinking during calcination [34]. However, a complementary explanation can be considered in view of the SAXS diffractograms (Fig. 2) that show the (100), (110) and (200) peaks characteristic of a highly ordered hexagonal mesoporous supports structure (p6mm) [17] for both silica but less intense and moreover split in two contributions for SBA-15. Considering the most intense (100) peak, these contributions correspond to unit-cell parameters of 110.6 and $106.6 \AA$ that suggest that SBA-15 1 is a physical mixture of partially uncalcined (less porous) and calcined (porous) silica grains.

Second, the pore volumes and pore diameters slightly decreased when SBA-15 (Fig. 1c) was submitted to the "two solvents" procedure (without metal addition) to give Ni-free $\mathrm{Ni}_{0} / \mathrm{SBA}-15_{2}$ (Fig. 1d). This revealed some textural instability of the mesoporous silica in the conditions of metal impregnation (and calcination), but the effect remained limited since $90 \%$ of the pore volumes and surface areas were preserved (Table 1). Furthermore, the mean pore diameter remained unchanged. In contrast, the mean pore diameter decreased by about 5\% (from $42 \AA$ to $40 \AA$ ) and even $8 \%$ (from $41 \AA$ to $38 \AA$ ) in the $\mathrm{Ni}_{\mathrm{x}} / \mathrm{SBA}-15_{1}$ and $\mathrm{Ni}_{\mathrm{x}} \mathrm{Ce}_{6} / \mathrm{SBA}-15_{2}$ series (Table 1), respectively, in strong agreement with the hypothesis of metal deposition inside the pores. Moreover, the shape of the hysteresis loop was then modified, with systematic deformation of the desorption branch (Fig. 1b, d and e). This is typical of partial plugging and limited access to the mesopores, further supporting the presence of oxide nanoparticles inside the pores.

Third, the porosity loss was of the same order of magnitude regardless of the Ni content (24-34\%, Table 1). It was slightly accentuated in the $\mathrm{Ni}_{\mathrm{x}} \mathrm{Ce}_{6} / \mathrm{SBA}-15_{2}$ series due to the co presence of $\mathrm{Ce}$ and $\mathrm{Ni}$ species in these samples and/or to the repetition of the impregnation treatments that may have provoked additional silica collapse, although limited. Also, small variations of the $\mathrm{pH}$ of the nickel nitrate solution during preparation, due to changes in metal concentration, could have played a role. It was the highest, around 4.5 , for the samples containing $2.5 \mathrm{wt} \% \mathrm{Ni}$, and decreased to 4.0 and 3.7 for the 5.0 and $7.5 \mathrm{wt} \%$ Ni content, respectively; it was around 4.0 during cerium addition.

\subsection{Structure, size and location of the supported nanoparticles}

Structural information on the deposited metal species in the calcined samples was gained from wide angle X-ray diffraction (Fig. 3). In all diffractograms, the SBA-15 support with amorphous 
silica walls gives a broad signal centered at about $22^{\circ}$ as well as a background that extends up to $90^{\circ}$, while progressively drifting towards higher intensity. The drift is accentuated for the metal richest samples. Since X-ray fluorescence is an atomic property that becomes inefficient if the emitters' atoms are located deeply inside the grains, this suggests an increase of the metallic species located outside the silica grains at high metal loadings.

The narrow peaks visible above the broad signal in the $\mathrm{Ni}_{\mathrm{x}} / \mathrm{SBA}-15_{1}$ series (Fig. $3 \mathrm{a}$ and $3 \mathrm{~b}$ ), with main peaks at $2 \Theta=37^{\circ}, 43^{\circ}$ and $62^{\circ}$, correspond to nickel oxide nanoparticles (JCPDS 04-0835) with a face-centered cubic lattice (Fm-3m) and a unit cell parameter equal to $4.17 \AA$. The intensity of the peaks increases with increasing nickel content, in line with a higher amount of nanoparticles in the metal-richer samples. On the contrary, the width of the peaks does not significantly vary from one sample to another, indicating that the mean particle size remains comparable regardless of the Ni content. From standard FWHM analysis, the average size of the $\mathrm{NiO}$ crystallographic domains is in the range $5-7 \mathrm{~nm}$ (Table 2) which is interestingly significantly smaller than the sizes reported in the literature (always above $10 \mathrm{~nm}$ ) for Ni based nanoparticles supported on $\mathrm{SiO}_{2}[35,36]$ or on mesoporous SBA-15 [21,37-41] with or without promoter.

In the $\mathrm{Ni}_{\mathrm{x}} \mathrm{Ce}_{6} / \mathrm{SBA}-15_{2}$ series of samples (Fig. 3c and 3d), a $\mathrm{NiO}$ pattern as above is present but together with new peaks at $2 \Theta=28,33,47,56$ and $69^{\circ}$ characteristic of face-centered cubic $\mathrm{CeO}_{2}$ crystalline nanoparticles with a cell parameter of 5.41 $\AA$ (JCPDS 075-5980). Using FWHM, the average size of the coherent domains for the $\mathrm{CeO}_{2}$ nanoparticles is found between 4 and $6 \mathrm{~nm}$, in the same range as for the $\mathrm{NiO}$ nanoparticles. Therefore, well dispersed $\mathrm{NiO}$ and $\mathrm{CeO}_{2}$ crystalline nanoparticles co-exist in the silica grains and the introduction of ceria previous to the $\mathrm{Ni}$ ions in the SBA-15 porous channels did not modify the characteristics of $\mathrm{NiO}$ nanoparticles formation.

The high dispersion of the supported metal oxide species was also confirmed by electron microscopy both in the scanning (Fig. 4) and transmission (Fig. 5) modes. The SEM images reveal that the SBA-15 silica supports are constituted of grains with rather homogeneous morphology, appearing in the form of slightly elongated rods with length between 0.6 and $1 \mu \mathrm{m}$ and 0.3 to $0.5 \mu \mathrm{m}$ in diameter (Fig. 4a). At high resolution, the linear channel system is easily distinguished (Fig. 4b). It is also well identified by TEM, even after Ni impregnation and calcination, as illustrated by the representative pictures taken parallel (Fig. 5a,b) or perpendicular (Fig. 5c) to the main axis of the silica grains. Thus, in agreement with porosity data (section 2.1), the linear porous system and the nanosized hexagonal pore apertures characteristic of the SBA-15 structure were well preserved in the prepared catalysts. Few amorphous silica deposits originating from the support syntheses were also noticed at the surface of the silica grains, but in low amounts (Fig. 5a). On the TEM images, the dispersed Ni-based nanoparticles appear in dark on the grey silica walls owing to their higher electronic density. They are present inside the pores (Fig. 5a-c) and are most often aligned along the channels, forming worm-like curved lines (Fig. 5b). In agreement with XRD, they show a reticular $\mathrm{d}_{012}$ distance of $2.1 \AA$ typical of NiO (zoom in Fig. $5 \mathrm{~d}$ ). Moreover, their mean size is around 5-6 nm (Table 2), slightly higher than the pore diameters (Table 1). Thus, the channels walls effectively contribute to high nickel dispersion by restricting the growth of the supported particles. As a result, the channels are partially filled, in line with the decrease in pore volumes discussed above. 
In the samples with limited $\mathrm{Ni}$ content ( 2.5 and $5 \mathrm{wt} \% \mathrm{Si}$ ), the nickel oxide nanoparticles were predominantly located inside the pores, with almost no particles visible outside, which illustrates the efficiency of the two solvent impregnation procedure towards predominant deposition of the metal species inside the channels. Nevertheless, bigger particles were identified on the surface of the silica grains at higher $\mathrm{Ni}$ content. These external supported metal species on $\mathrm{Ni}$.5/SBA-15 were detected by not only TEM (Fig. 6a) but also by SEM on the images recorded in a partial retro-diffused mode where the heavier elements (here Ni) appear more brilliant (Fig. 4c). These various features were unchanged whether the sample contained or not Ce.

Although well dispersed, the nanoparticles were not homogeneously distributed among the silica grains in both $\mathrm{Ni}_{\mathrm{x}} / \mathrm{SBA}-15_{1}$ and $\mathrm{Ni}_{\mathrm{x}} \mathrm{Ce}_{6} / \mathrm{SBA}-15_{2}$ series. Indeed, the pores of some grains remained empty while others contained high number of nanoparticles. Also, the $\mathrm{Ni}$ concentration not only varied from one grain to another but also changed in a same grain depending on the zone. Moreover, in the Ce containing samples, some grains contained both elements whereas others were enriched with only $\mathrm{Ce}$ or $\mathrm{Ni}$ as measured by EDS. Thus, the local atomic $\mathrm{Ni} / \mathrm{Si}$ ratios in $\mathrm{Ni}$ containing zones were between 0.04 and 0.07 in $\mathrm{Ni}_{2.5} / \mathrm{SBA}-15_{1}$, around 0.08 in $\mathrm{Ni}_{5} / \mathrm{SBA}-15_{1}$ and in the range 0.09-0.17 in $\mathrm{Ni}_{7.5} / \mathrm{SBA}-15_{1}$. Taking into account that some grains are empty, these values are in good agreement with the global atomic $\mathrm{Ni} / \mathrm{Si}$ ratios of $0.034,0.068$ and 0.1 expected from the amount of $\mathrm{Ni}$ impregnated on these samples, respectively. In the $\mathrm{Ni}_{\mathrm{x}} \mathrm{Ce}_{6} / \mathrm{SBA}-15_{2}$ series, $\mathrm{Ce}$ was even more heterogeneously localized since the atomic $\mathrm{Ce} / \mathrm{Si}$ ratio was as high as 0.16 in some grains (i.e. much higher than the value of 0.025 expected for $6 \mathrm{wt} \% \mathrm{Ce})$. It is worth adding that the Ce-enriched grains could be easily distinguished in the TEM pictures due to their much darker appearance than for the $\mathrm{Ce}$ free grains and to the presence of small $\mathrm{CeO}_{2}$ nanoparticles shaped into small dots (Fig. $6 b)$.

\subsection{Catalytic activity}

Before catalytic tests, the calcined samples were reduced in flowing $5 \% \mathrm{H}_{2} / \mathrm{Ar}$ at $650^{\circ} \mathrm{C}$ $\left(10^{\circ} \mathrm{C} \cdot \mathrm{min}^{-1}\right)$. At this temperature, the $\mathrm{NiO}$ nanoparticles were fully transformed into metallic $\mathrm{Ni}^{0}$ as confirmed by TPR (data not shown) that indicated that the reduction took place in two main steps, at around 390 and $600^{\circ} \mathrm{C}$ in all catalysts. This agrees with previous works [41-44] that assigned the low temperature peak to the reduction of $\mathrm{NiO}$ nanoparticles in weak interaction with the support while that at high temperature would rather correspond to isolated Ni-ions in strong interactions with the silica walls. As expected, the hydrogen consumption increased with the nickel content and the proportion of nickel in weak interaction increased simultaneously. No significant difference in the nickel reduction process between the samples with and without ceria was noted.

After reduction at $650^{\circ} \mathrm{C}$ for $2 \mathrm{~h}$, the temperature was cooled down to $200^{\circ} \mathrm{C}$, then the $5 \% \mathrm{H}_{2} / \mathrm{Ar}$ flow was switched to that of reactants and the evolution of the $\mathrm{CH}_{4}$ and $\mathrm{CO}_{2}$ conversions was followed while increasing the temperature from 200 to $800^{\circ} \mathrm{C}$ (light-off curves). Figure 7 (left 
side) shows the evolutions of conversions of $\mathrm{CH}_{4}$ (Fig. 7A) and $\mathrm{CO}_{2}$ (Fig. 7B) as well as of selectivities $\left(\mathrm{H}_{2} / \mathrm{CO}\right.$ molar ratio, Fig. 7C) as a function of temperature for some representative samples; Table 3 details the values obtained at 500 and $650^{\circ} \mathrm{C}$ for all samples, using either $20 \mathrm{mg}$ or $100 \mathrm{mg}$ of catalyst (264 and $52.8 \mathrm{~L} \cdot \mathrm{g}^{-1} \cdot \mathrm{h}^{-1}$, respectively).

First, for all Ni-containing SBA-15 $11_{1}$ catalysts, the $\mathrm{CH}_{4}$ conversions were between $40 \%$ and $65 \%$ at $500^{\circ} \mathrm{C}$ and close to $100 \%$ at $650^{\circ} \mathrm{C}$ (Table 3 and Fig. $7 \mathrm{~A}$ ). These values are much higher than those attained on the reference $\mathrm{Ni}_{5} / \mathrm{SiO}_{2}$ catalyst supported on fumed silica, even if the latter was tested at lower space velocity (Table 3). This reveals the excellent catalytic behavior of all $\mathrm{Ni}_{\mathrm{x}} / \mathrm{SBA}-15_{1}$ samples. Second, the regular increase of both $\mathrm{CH}_{4}$ and $\mathrm{CO}_{2}$ conversions with temperature (Fig. 7A, B) validates the endothermic character of the reaction. Third, the increase of the nickel content from $2.5 \mathrm{wt} \%$ to $7.5 \mathrm{wt} \%$ resulted in a slight amelioration of the catalytic activity, yet very low compared to the active phase content that is three times higher. This suggests some accessibility hindrance to the active sites and/or diffusional limitations, as also supported by the comparable conversions attained when using 20 or $100 \mathrm{mg}$ of catalyst (Table 3). These limitations can be related to a more difficult access to the $\mathrm{Ni}^{0}$ particles blocked inside the channels. In spite of these restrictions, $\mathrm{Ni}^{0}$ plays an essential role in the reaction since neither the SBA-15 support alone, nor a $\mathrm{Ce}_{6} / \mathrm{SBA}-15$ sample tested for comparison, were active (data not shown). Fourth, the presence of $\mathrm{Ce}$ in the $\mathrm{Ni}_{\mathrm{x}} \mathrm{Ce} / \mathrm{SBA}-15_{2}$ series did not enhance the catalytic activity in the test conditions used (Fig. 7 and Table 3) compared to the Ce-free samples. Therefore, in agreement with recent reports [21,45], the promoting effect frequently reported upon ceria addition on $\mathrm{Ni}$ catalysts working in DRM at high reaction temperatures (above $700^{\circ} \mathrm{C}$ ) and for longer times [19-23] is no longer evident when medium temperatures are applied.

It can also be noticed that the conversion of $\mathrm{CH}_{4}$ for all catalysts is slightly higher than that of $\mathrm{CO}_{2}$ (Fig. 7 and Table 3). This may indicate some methane decomposition as secondary reaction $[46,47]$ but at a very small extent, in line with the limited formation of carbon deposits (especially nanotubes) as will be further discussed from electron microscopy data (section 3.5). Also, it can be recalled that some kinds of carbon nanotubes do not affect the stability of the catalysts [47].

Finally, a last interesting point to mention is the very high $\mathrm{CH}_{4}$ conversion achieved, with values significantly higher than those commonly reported for this reaction in the same temperature range [48]. Lotina et al. [46] noted a similar trend with Ni-based mixed oxide (from hydrotalcite) catalysts and attributed it to the occurrence of secondary reactions like RWGS, methane decomposition and steam reforming. However, such secondary reactions should remain negligible in view of the $\mathrm{H}_{2}$ :CO ratios close to one and of the limited coke amount (as above mentioned). Then, another interpretation could be raised, involving a membrane effect already proposed by Haag et al. [49] and Munera et al. [50] when using catalytic membrane reactor for dry reforming of methane. By analogy, the $\mathrm{Ni}_{\mathrm{x}} / \mathrm{SBA}-15$ catalysts could be considered as membrane reactors in which diffusion of the reactants and products could vary depending on the chemical nature and size of the compound. The easier diffusion of the small $\mathrm{H}_{2}$ molecules (product of reaction) compared to reagents $\left(\mathrm{CH}_{4}\right.$ and $\left.\mathrm{CO}_{2}\right)$ and other products $\left(\mathrm{CO}\right.$ and $\left.\mathrm{H}_{2} \mathrm{O}\right)$ could thus displace the reaction towards products and lead to conversions higher than expected from thermodynamic equilibrium. This could also contribute to the slight superiority of the $\mathrm{CH}_{4}$ conversion compared 
that of $\mathrm{CO}_{2}$, the RWGS reaction being inhibited in the absence of $\mathrm{H}_{2}$ (diffusing rapidely outside the pores). However, the most probable explanation lies in the diluted gas mixtures used during the tests (see section 2.3). Indeed, the conversions obtained in such conditions were in fact very close to the thermodynamic equilibrium values of $0.96\left(\mathrm{CH}_{4}\right)$ and $0.97\left(\mathrm{CO}_{2}\right)$ calculated with the HSC chemistry software (where $\mathrm{H}, \mathrm{S}$ and $\mathrm{C}$ stand for enthalpy, entropy and heat capacity, respectively) when considering the experimental $\mathrm{CH}_{4}$ and $\mathrm{CO}_{2}$ dilution conditions applied at 1 bar and $650^{\circ} \mathrm{C}$. Such dilution effect was to our knowledge never stressed out before and work is in progress to confirm this interpretation (to be published).

\subsection{Catalytic stability and selectivity}

After reduction and light-off tests carried out as above (step A, Fig. 8a), the catalytic stability of all catalysts was followed at $500^{\circ} \mathrm{C}$ for $12 \mathrm{~h}$ (step B to C, Fig. 8a). This medium temperature was chosen in this section for two reasons. Firstly, as deduced above from the light off curves (Fig. $7 \mathrm{~A}, \mathrm{~B})$, it gives intermediate conversions (40-60\%, not too high) that are appropriate to study the evolution of activity with time. Secondly, operating at $500^{\circ} \mathrm{C}$ would allow using such catalysts in membrane reactors where the hydrogen permeation flux declines if the membrane is submitted to temperature above $550^{\circ} \mathrm{C}$ [51]. To the best of our knowledge, only few works dealing with the stability behavior of $\mathrm{Ni}$ based catalysts at low temperatures have been published [52-57].

For all samples, the $\mathrm{CH}_{4}$ conversions (Fig. 7A'), $\mathrm{CO}_{2}$ conversions (Fig. 7B') and $\mathrm{H}_{2}: \mathrm{CO}$ ratios (Fig. 7C') were very stable with time on stream, thus revealing the high stability of the catalysts at the applied temperature. Moreover, both carbon and hydrogen balances were found excellent, in the range 95-100\%. Even more interesting, as represented in Fig. 8b, slightly better conversions were obtained at $500^{\circ} \mathrm{C}$ at step B (i.e. after cooling the temperature from $800^{\circ} \mathrm{C}$ back to $500^{\circ} \mathrm{C}$ ), compared to step A (i.e. during light-off curve), regardless of the nickel content. This can be due to differences in heat and mass transfer between the transition (step A) and steady state (steps B and $\mathrm{C}$ ) regimes.

Also, it can indicate some beneficial transformation of the nickel species (for instance better reduction) and/or enhanced accessibility of the reactants after intermediate heating of the samples at high temperature $\left(800^{\circ} \mathrm{C}\right.$ between steps $\mathrm{A}$ and B, Fig. 8a). After $12 \mathrm{~h}$ (step C, Fig. 8), the conversions were almost unchanged, demonstrating further the very stable behaviors of the mesoporous catalysts under the employed conditions. Moreover, as for conversions, the addition of Ce did not play a major role on stability at this temperature.

In addition, not only the stability but also the selectivity towards DRM was excellent at $500^{\circ} \mathrm{C}$, whatever the sample and the catalytic step, as seen from the $\mathrm{H}_{2}: \mathrm{CO}$ ratios close to one (Fig. 8c), that is the theoretical expected value for DRM (production of $\mathrm{H}_{2}$ and $\mathrm{CO}$ in equimolar composition). Nevertheless, the quantity of produced $\mathrm{H}_{2}$ was not strictly twice that of methane (data not detailed), contrarily to what should occur in ideal stoichiometric conditions. This indicates that some limited $\mathrm{CH}_{4}$ decomposition starts to take place at $500^{\circ} \mathrm{C}$ and is accentuated at higher temperatures [58,59]. This also agrees with the slightly higher $\mathrm{CH}_{4}$ conversion compared to that of $\mathrm{CO}_{2}$ seen above on these catalysts (section 3.3). 


\subsection{High and stable nickel dispersion in the SBA-15 supports}

From above data, the $\mathrm{Ni}_{\mathrm{x}} / \mathrm{SBA}-15_{1}$ and $\mathrm{Ni}_{\mathrm{x}} \mathrm{Ce}_{6} / \mathrm{SBA}-15_{2}$ series of samples prepared by the "two solvents" method have very good catalytic behaviors in DRM, even much better than those recently reported on Ni-based SBA-15 materials prepared with classical methods of impregnations and higher $\mathrm{Ni}$ loading (Fig. 9). Indeed, more than $80 \% \mathrm{CH}_{4}$ conversion was achieved at $600^{\circ} \mathrm{C}$ in this work whereas at the same temperature it reached only $45 \%$ on $12 \%$ Ni/SBA-15 [20] and varied between 5 and $65 \%$ for other $10 \% \mathrm{Ni} / \mathrm{SBA}-15$ catalysts $[21,39,60,61]$. With the Ceria or Ceria-zirconia (CZ) promotion, the $\mathrm{CH}_{4}$ conversion exceeded $96 \%$ in this work while only 44 and $60 \%$ conversions were achieved for $12 \%$ NiCe/SBA-15 [20] and $10 \%$ Ni/CZ/SBA-15 [21,45] catalysts, respectively. Moreover, an almost equimolar $\mathrm{H}_{2}$ and $\mathrm{CO}$ composition was attained on our catalysts, as for a $10 \% \mathrm{Ni}-\mathrm{CZ} / \mathrm{SBA}-15$ material [21], while the $\mathrm{H}_{2}$ : CO ratio was between 0.7 and 0.8 (i.e. notably lower than 1) on Ni-Ce/SBA-15 [20] and ceriadoped Ni/SBA-16 catalysts [24].

In view of the TEM and XRD results discussed above, the high activity of both $\mathrm{Ni}_{\mathrm{X}} / \mathrm{SBA}-15_{1}$ and $\mathrm{Ni}_{\mathrm{x}} \mathrm{Ce}_{6} / \mathrm{SBA}-15_{2}$ series of catalysts can be evidently explained by the excellent $\mathrm{Ni}$ dispersion seen after calcination and maintained after reduction and catalytic testing. Indeed, in the spent catalysts (i.e. $12 \mathrm{~h}$ at $500^{\circ} \mathrm{C}$ ), diffraction peaks at $2 \theta=44^{\circ}, 52^{\circ}$ and $76^{\circ}$ are observed for all samples (Fig. 10), assignable to metallic $\mathrm{Ni}^{0}$ with a face-centered cubic lattice (Fm-3m) and a unit cell parameter of $3.51 \AA$ (JCPDS 71-4655). Note that some presence of $\mathrm{Ni}_{0.98} \mathrm{C}_{0.02}$ (JCPDS74-5561) with typical diffraction peaks at the same position cannot be excluded. These signals confirm the preservation of the reduction state of the nickel active phase in the DRM reaction. More importantly, the mean crystallite sizes of the Ni particles calculated using the Scherrer equation on these samples are between 5 and $8 \mathrm{~nm}$ (Table 2), which is very close, only slightly higher, than the sizes identified before test for the $\mathrm{NiO}$ particles in the calcined samples (Table 2). Therefore, if present, the sintering of the supported nanoparticles during reduction and along the reaction remained very limited. Moreover, with respect to $\mathrm{Ce}$, the $\mathrm{CeO}_{2}$ peaks were no longer detected after test and either no peaks or very small ones assignable to partially reduced $\mathrm{CeO}_{1.675}$ (898430), were found, depending on the sample. This suggests cerium spreading upon reductive thermal treatments possibly in the form of $\mathrm{Ce}^{3+}$ or $\mathrm{Ce}^{4+}$ ions and/or formation of non-crystalline phases.

The high $\mathrm{Ni}^{0}$ dispersion in the spent catalysts was further attested by the TEM pictures that simultaneously confirmed preservation of both the mesoporous channel system and the ordered hexagonal structure after test (Fig. 11a,b) as well illustrated by representative images of $\mathrm{Ni}_{5} / \mathrm{SBA}$ $15_{1}$ (Fig. 11a,b) and $\mathrm{Ni}_{7.5} \mathrm{Ce}_{6} / \mathrm{SBA}-15_{2}$ (Fig. 11c). No difference between Ni/SBA-15 and NiCe/SBA-15 catalysts has been observed. This result was expected since the presence of ceria didn't affect the catalytic activity/stability of the catalysts under our experimental conditions.

As for the calcined samples, no external Ni particles were observed and this was also surprisingly the case for $\mathrm{Ni}_{7.5} / \mathrm{SBA}-15_{1}$ on which external particles were present after calcination. The disappearance of these external particles, also confirmed by SEM (Fig. 4d), could be due to their removal during reductive and heat treatments due to a low mechanical stability (weak interaction with the surface) in the high gas flow. Also, these external particles may have participated to coke 
formation in the form of carbon nanotubes, a process that is known to take place at the interface between the $\mathrm{Ni}^{0}$ active species and the support [61]. In such case, the nickel metal particles are progressively pushed away from the surface, which can occur with particles deposited outside the pores, as was indeed observed - although rarely - on the spent $\mathrm{Ni}$ richest $\mathrm{Ni}_{7.5} / \mathrm{SBA}-15$ catalyst (Fig. 11e). In contrast, such carbon nanotubes formation is totally hindered inside the SBA-15 pores due to steric constraints and to the stabilization of the small $\mathrm{Ni}^{0}$ nanoparticles that remain strongly attached and blocked in the pores. An additional confirmation of the preservation of the nickel dispersion after catalytic run is given by the atomic $\mathrm{Ni} / \mathrm{Si}$ ratio values (EDS analyses) that stayed globally comparable to those after calcination in both $\mathrm{Ni} / \mathrm{SBA}-15_{1}$ and $\mathrm{NiCe} / \mathrm{SBA}-15_{2}$ series (Table 2).

The importance of $\mathrm{Ni}$ dispersion for catalytic efficiency in DRM and the very positive confinement effect seen here and provided by the SBA-15 support were already discussed [27,41,61-65]. On the one hand, the confinement limits the growth of the Ni particles to few nanometers during pre-treatment and reaction and results in a better $\mathrm{Ni}$ dispersion. Consequently, the number of accessible $\mathrm{Ni}^{0}$ nanoparticles inside the pores and therefore of available active sites increases (even if some nickel is not easily accessible). Compared to previous bibliographic reports on Ni/SBA-15 catalysts, the effect is here strongly accentuated owing to the "two solvents" metal deposition method used for the catalysts preparation that permitted a significant increase of the dispersion of nickel deep inside the pores [26-28]. Interestingly, very small and efficient nickel particles were also recently obtained by immobilizing premade Ni nanoparticles onto functionalized silica then coating the $\mathrm{NiO} / \mathrm{SiO}_{2}$ catalyst with silica overlayers to enable the transfer of reactants and products while preventing aggregation of the Ni nanoparticles [66]. On another hand, the SBA-15 support presents the important additional advantages to inhibit coke formation by confinement effect, thus enabling high conversions even at low temperature $\left(500^{\circ} \mathrm{C}\right)$. Moreover, as previously proposed [65,67], the mesoporous support can also help to minimize the heat diffusion problems usually encountered with the endothermic DRM reaction, by avoiding the formation of cold points in the catalyst bed that can hinder diffusion.

\section{Conclusions and perspectives}

High dispersion of nickel and cerium inside the channels of mesoporous SBA-15 was obtained using the "two solvents" deposition method. The catalysts reduced and tested in DRM show high activity up to $800^{\circ} \mathrm{C}$ and excellent stability at $500^{\circ} \mathrm{C}$ for $12 \mathrm{~h}$. Complete methane conversion is obtained below $650^{\circ} \mathrm{C}$. Due to its large specific surface area and pore volume together with uniform and ordered mesopore distribution, the SBA-15 matrix stabilizes the nickel nanoparticles inside the pores, thus inhibiting their sintering and reducing coke formation during reaction. Under our reaction conditions, no effect of ceria was observed. After reaction, Ni metallic particles, stable in air, are observed inside the pores with a good dispersion while no ceria is detected. The use of the "two solvents" method permits the preparation of highly active and stable Ni/SBA-15 catalysts for dry reforming of methane. Additional tests under higher temperature and pressure are being elaborated in order to extrapolate these excellent catalytic behaviors to more severe catalytic conditions. 
Authors are grateful to the UOB research council (BIRG 14/2012) and to the "Agence Universitaire de la Francophonie" (AUF) for their financial supports. Dr. A. El Samarani is acknowledged for XRD experiments in Lebanese University, Hadath. Authors also thank P. Davidson, physicist at the Laboratoire de Physique des solides, Universite Paris - Sud 11 for registration of SAXS data. 
[1] Bartholomew $\mathrm{CH}$ and Farrauto RJ, Fundamentals of Industrial Catalytic Processes, New York: Wiley, 2006, pp.338-486.

[2] I. Wender, Fuel Process. Technol. 48 (1996) 189-297.

[3] V. Choudhary and K. Mondal, Appl. Energy 83 (2006) 1024-1032.

[4] G. Gallego, B. Dupeyart, J. Barrault, E. Florez and F. Mondragon, Appl. Catal. A. 334 (2008) 251-258.

[5] D. Li, Y. Nakagawa and K. Tomishige, Appl. Catal. A. 408 (2011) 1-24.

[6] D. Pakhare and J. Spivey, RSC Chem. Soc. Rev. (2014) DOI: 10.1039/c3cs60395d.

[7] M. Rezaei, S.M. Alavi, S. Sahebdelfar and Z. Yan, J. Nat. Gas Chem. 15 (2006) 327-334.

[8] A.I. Tsyganok, M. Inaba, T. Tsunoda, S. Hamakawa, K. Suzuki and T. Hayakawa, Catal. Commun. 4 (2003) 493-498.

[9] R. Ding, Z. Yan, L. Song and X. Liu, J. Nat. Gas. Chem. 10(3) (2001) 237-255.

[10] M.C.J. Bradford and M.A. Vannice, Catal. Rev. Sci. Eng. 41(1) (1999) 1-42.

[11] Z. Hou, P. Chen, H. Fang, X. Zheng and T. Yashima, Int. J. Hydrogen Energy. 31 (2006) 555561.

[12] W. K. Jozwiak, M. Nowosielska and J. Rynkowski, Appl. Catal. A. 280 (2005) 233-244.

[13] H. Arbag, S. Yasyerli, N. Yasyerli and G. Dogu, Int. J. Hydrogen Energy. 35(6) (2010) 22962304.

[14] I. Silverwood, N. Hamilton, C. Laycock, J. Staniforth, M. Ormerod, C. Frost, S. Parker and D. Lennon, Phys. Chem. Chem. phys. 12 (2010) 3102-3107.

[15] H. Eltejaei, H. Reza Bozorgzadeh, J. Towfighi, M. Reza Omidkhah, M. Rezaei, R. Zanganeh, A. Zamaniyan and A. Zarrin Ghalam, Int. J. Hydrogen Energy. 37 (2012) 4107-4118.

[16] J. Juan-Juan, M.C. Roman-Martinez and M.J. Illan-Gomez, Appl. Catal. A. 355 (2009) 27-32.

[17] C. Zhang, W. Zhu, S. Li, G. Wu, X. Ma, X. Wang and J. Gong, Chem. Commun. 49 (2013) 9383-9385.

[18] Q. Ma, D. Wang, M. Wu, T. Zhao, Y. Yoneyama and N. Tsubaki, Fuel. 108 (2013) 430-438.

[19] A. Khan, T. Sukonket, B. Saha and R. Idem, Energy Fuels. 26 (2012) 365-379.

[20] N. Wang, W. Chu, T. Zhang and X.S. Zhao, Int. J. Hydrogen Energy. 37 (2012) 19-30.

[21] A. Albarazi, P. Beaunier and P. Da Costa, Int. J. Hydrogen Energy. 38 (2013) 127-139.

[22] A. Nandini, K. K. Pant and S. C. Dhingra, Appl. Catal. A. 290(1-2) (2005) 166-174.

[23] N. Laosiripojana, W. Sutthisripok and S. Assabumrungrat, Chem. Eng. J. 112(1-3) (2005) 1322.

[24] S. Zhang, S. Muratsugu, N. Ishiguro and M. Tada, ACS Catal. 3 (2013) 1855-1864.

[25] H. Wan, X. Li, S. Ji, B. Huang, K. Wang and C. Li, J. Nat. Gas Chem. 16 (2007) 139-147.

[26] M. Imperor-Clerc, D. Bazin, M. Appay, P. Beaunier and A. Davidson, Chem. Mater. 16 (2004) 1813-1821.

[27] I. Lopes, N. El Hassan, H. Guerba, G. Wallez and A. Davidson, Chem. Mater. 18 (2006) 58265828.

[28] J. Van der Meer, I. Bardez-Giboire, C. Mercier, B. Revel, A. Davidson and R.J. Denoyel, J. Phys. Chem. C. 114 (2010) 3507-3515. 
[29] J. Taghavimoghaddam, G. P. Knowles and A.L. Chaffee, J. Mol. Catal. A. 377 (2013) 115-122.

[30] M. Cabo, E. Pellicer, E. Rossinyol, P. Solsona, O. Castell, S. Surinach and M. Dolors Baro, J. Nanopart. Res. 13 (2011) 3671-3681.

[31] Li Guo-Min, W. Lian-Cheng and X. Yao, Chin. Phys. B. 23(8) (2014) 088105.

[32] D. Zhao, J. Feng, Q. Huo, N. Melosh, G.H. Fredrickson, B.F. Chmelka and G.D. Stucky, Science. 279 (1998) 548-552.

[33] E. Paineau, I. Dozov, P. Adrian-Marie, I. Bihannic, F. Meneau, C. Baravian, L. Michot and P. Davidson, J. Phys. Chem. B. 116 (2012) 13516-13524.

[34] F. Boubekr, A. Davidson, S. Casale and P. Massiani, Microporous and Mesoporous Mater. 141 (2011) 157-166.

[35] X. Lv,J. Chen, Y. Tan and Y. Zhang, Catal. Commun. 20 (2012) 6-11.

[36] J. Zhu, X. Peng, L. Yao, X. Deng, H. Dong, D. Tong and C. Hu, Int. J. Hydrogen Energy. 38 (2013) 117-126.

[37] H. Zhang, M. Li, P. Xiao, D. Liu and C.J. Zou, Chem. Eng. Technol. 36(10) (2013) 1701-1707.

[38] Z.J. Zuo, C.F. Shen, P.J. Tan and W. Huang, Catal. Commun. 41 (2013) 132-135.

[39] N. Wang, X. Yu, K. Shen, W. Chu and W. Qian, Int. J. Hydrogen Energy. 38 (2013) 97189731.

[40] J. Sietsma, J. Meeldijk, M. Versluijs-Helder, A. Broersma, A. Jos van Dillen, P. de Jongh and K. de Jong, Chem. Mater. 20 (2008) 2921-2931.

[41] F. Habimana, X. Li, S. Ji, B. Lang, D. Sun, C. Li, J. Nat. Gas Chem. 18 (2009) 392-398.

[42] K. Wang, X. Li, S. Ji, X. Shi and J. Tang, Energy Fuels. 23 (2009) 25-31.

[43] B.S Liu and C.T. Au, Appl. Catal. A. 244 (2003) 181-195.

[44] H. Liu, H. Wang, J. Shen, Y. Sun and Z. Liu, Appl. Catal. A. 337 (2008) 138-147.

[45] A. Albarazi, M.E. Galvez, P. Da Costa, Catal. Commun. 59 (2015) 108-112.

[46] A. Serrano-Lotina and L. Daza, Int. J. Hydrogen Energy. 39 (2014) 4089-4094.

[47] H. Wu, G. Pantaleo, V. La Parola, A. M. Venezia, X. Collard, C. Aprile and L. F. Liotta, Appl.

Catal. B. 156-157 (2014) 350-361.

[48] B. Nagaraja, D. Bulushev, S. Beloshapkin, S. Chansai and J. Ross, Top Catal. 56 (2013) 16861694

[49] S. Haag, M. Burgard and B. Ernst, J. Catal. 252 (2007) 190-204.

[50] J. Múnera, B. Faroldi, E. Frutis, E. Lombardo, L. Cornaglia and S. González Carrazán, Appl. Catal. A. 474 (2014) 114-124.

[51] P. Ferreira and M. Benito, Ind. Eng. Chem. Res. 44 (2005) 742-748.

[52] S. Sokolov, E. Kondratenko, M. Pohl, A. Barkschatr and U. Rodemerck, Appl. Catal. B. 113114 (2012) 19-30.

[53] S. Sokolov, E. Kondratenko, M. Pohl and U. Rodemerck, Int. J. Hydrogen Energy. 38 (2013) 16121-16132.

[54] P. Ferreira-Aparicio, A. Guerrero-Ruiz and I. Rodriguez-Ramos, Appl. Catal. A. 170 (1998) 177-187.

[55] S. Irusta, L.M. Cornaglia and E.A. Lombardo, J. Catal. 210 (2002) 263-272.

[56] D. Baudouin, U. Rodemerck, F. Krumeich, A. Mallmann, K. Szeto, H. Menard, L. Veyre, J. Candy, P. Webb, C. Thieuleux and C. Coperet, J. Catal. 297 (2013) 27-34. 
[57] X. Xie, T. Otremba, P. Littlewood, R. Schomacker and A. Thomas, ACS Catal. 3 (2013) 224229.

[58] J.Z. Luo, Z.L. Yu, C.F. Ng and C.T. Au, J. Catal. 194 (2000) 198-210.

[59] E. Daza, J. Gallego, F. Mondragón, S. Moreno and R. Molina, Fuel. 89 (2010) 592-603.

[60] B. Li and S. Zhang, Int. J. Hydrogen Energy. 38 (2013) 14250-14260.

[61] M. E. Gálvez, A. Albarazi and P. Da Costa, Appl. Catal. A, In press

[62] T. Huang, W. Huang, J. Huang and P. Ji, Fuel process. Technol. 92 (2011) 1868-1875.

[63] A. Brungs, A. York, J. Claridge, C. Marquez-Alvarez and M. Green, Catal. Letters. 70 (2000) 117-122.

[64] A. Djaidja, S. Libs, S. Kiennemann and A. Barama, Catal. Today. 113 (2006) 194-200.

[65] L. Xu, H. Song and L. chou, Int. J. Hydrogen Energy. 38 (2013) 7307-7325.

[66] J. W. Han,C. Kim, J. P. Park and H. Lee, Chem. Sus. Chem. 7(2) (2014) 451-456.

[67] N. Wang, X. Yu, Y. Wang, W. Chu and M. Liu, Catal. Today. 212 (2013) 98-107. 
Table 1. Textural properties of the catalysts

\begin{tabular}{|c|c|c|c|c|c|c|c|}
\hline \multirow[b]{2}{*}{ Sample } & \multicolumn{2}{|c|}{$\begin{array}{c}\text { Transition metal } \\
\text { content (wt } \% \text { ) }\end{array}$} & \multicolumn{2}{|c|}{ Surface area } & \multicolumn{2}{|c|}{$\begin{array}{c}\text { Pore volume } \\
\left(\mathrm{cm}^{3} \cdot \mathrm{g}^{-1}\right)\end{array}$} & \multirow{2}{*}{$\begin{array}{l}\text { Mean Por } \\
\operatorname{size}^{* *}(\AA)\end{array}$} \\
\hline & $\mathrm{Ni}$ & $\mathrm{Ce}$ & $\begin{array}{c}\text { Total } \\
\left(\mathrm{m}^{2} \cdot \mathrm{g}^{-1}\right)\end{array}$ & $\begin{array}{c}\text { Loss after } \\
\text { metal } \\
\text { addition } \\
*(\%)\end{array}$ & micropores & mesopores & \\
\hline SBA- $15_{1}$ & - & - & 455 & 0 & 0.06 & 0.45 & 42 \\
\hline $\mathrm{Ni}_{2.5} / \mathrm{SBA}-15_{1}$ & 2.5 & - & 348 & 24 & 0.04 & 0.39 & 40 \\
\hline $\mathrm{Ni}_{5.0} / \mathrm{SBA}-15_{1}$ & 5.0 & - & 320 & 30 & 0.03 & 0.35 & 40 \\
\hline $\mathrm{Ni}_{7.5} / \mathrm{SBA}-15_{1}$ & 7.5 & - & 348 & 24 & 0.04 & 0.43 & 41 \\
\hline SBA- $15_{2}$ & - & - & 632 & 0 & 0.09 & 0.53 & 41 \\
\hline $\mathrm{Ni}_{0} / \mathrm{SBA}-15_{2}$ & 0 & - & 571 & 10 & 0.08 & 0.50 & 41 \\
\hline $\mathrm{Ni}_{5.0} \mathrm{Ce}_{6} / \mathrm{SBA}-15_{2}$ & 5.0 & 6 & 419 & 34 & 0.06 & 0.32 & 38 \\
\hline $\mathrm{Ni}_{7.5} \mathrm{Ce}_{6} / \mathrm{SBA}-15_{2}$ & 7.5 & 6 & 468 & 26 & 0.06 & 0.36 & 38 \\
\hline $\mathrm{Ni}_{5} / \mathrm{SiO}_{2}$ & 5.0 & - & 237 & & - & - & - \\
\hline
\end{tabular}

*: loss of surface area compared to parent silica (in \%)

**: mean pore size $( \pm 1 \AA)$ estimated from BJH method 
Table 2. Estimated average particles size for the calcined and spent catalysts

\begin{tabular}{|c|c|c|c|c|c|c|}
\hline \multirow{3}{*}{ Sample Name } & \multicolumn{3}{|c|}{ Calcined Catalysts } & \multicolumn{3}{|c|}{ Spent Catalysts } \\
\hline & \multicolumn{2}{|c|}{$\varnothing \mathrm{NiO}(\mathrm{nm})$} & \multirow{2}{*}{$\begin{array}{c}\mathrm{Ni} / \mathrm{Si} \\
\text { atomic ratio }^{* *}\end{array}$} & \multicolumn{2}{|c|}{$\varnothing \mathrm{Ni}^{0}(\mathrm{~nm})$} & \multirow{2}{*}{$\begin{array}{c}\mathrm{Ni} / \mathrm{Si} \\
\text { atomic ratio*** }\end{array}$} \\
\hline & XRD* & $\mathrm{TEM}^{* *}$ & & XRD* & $\mathrm{TEM}^{* *}$ & \\
\hline $\mathrm{Ni}_{2.5} / \mathrm{SBA}-15_{1}$ & 7 & 6 & $0.04-0.07$ & n.d. & 8 & 0.04-0.09 \\
\hline $\mathrm{Ni}_{5} / \mathrm{SBA}-15_{1}$ & 5 & 5 & $0.07-0.08$ & 8 & n.d. & n.d. \\
\hline $\mathrm{Ni}_{7.5} / \mathrm{SBA}-15_{1}$ & 5 & 6 & $0.09-0.17$ & 4 & 5 & $0.16-0.19$ \\
\hline $\mathrm{Ni}_{2.5} \mathrm{Ce}_{6} / \mathrm{SBA}-15_{2}$ & 6 & 7 & $0.04-0.14$ & n.d. & n.d. & $0.03-0.05$ \\
\hline $\mathrm{Ni}_{5} \mathrm{Ce}_{6} / \mathrm{SBA}-15_{2}$ & 5 & 7 & $0.05-0.20$ & n.d. & n.d. & n.d. \\
\hline $\mathrm{Ni}_{7.5} \mathrm{Ce}_{6} / \mathrm{SBA}-15_{2}$ & 5 & 5 & $0.12-0.32$ & 5 & n.d. & $0.08-0.35$ \\
\hline $\mathrm{Ni}_{5} / \mathrm{SiO}_{2}$ & 13 & n.d. & n.d. & 13 & n.d. & n.d. \\
\hline
\end{tabular}

*Calculated using Sherrer equation

**From TEM images of calcined and spent catalysts n.d.: not determined 
Table 3. Conversion and selectivity values on the different catalysts (as deduced from light off curves)

\begin{tabular}{|c|c|c|c|c|c|c|c|c|c|c|c|c|}
\hline GHSV & \multicolumn{6}{|c|}{52.8} & \multicolumn{6}{|c|}{264} \\
\hline Temperature & \multicolumn{3}{|c|}{500} & \multicolumn{3}{|c|}{650} & \multicolumn{3}{|c|}{500} & \multicolumn{3}{|c|}{650} \\
\hline & $\mathrm{CH}_{4}$ & $\mathrm{CO}_{2}$ & $\mathrm{H}_{2}: \mathrm{CO}$ & $\mathrm{CH}_{4}$ & $\mathrm{CO}_{2}$ & $\mathrm{H}_{2}: \mathrm{CO}$ & $\mathrm{CH}_{4}$ & $\mathrm{CO}_{2}$ & $\mathrm{H}_{2}: \mathrm{CO}$ & $\mathrm{CH}_{4}$ & $\mathrm{CO}_{2}$ & $\mathrm{H}_{2}: \mathrm{CO}$ \\
\hline $\mathrm{Ni}_{2.5} / \mathrm{SBA}-15_{1}$ & 40 & 42 & 0.85 & 97 & 85 & 1.01 & 42 & 38 & 0.85 & 86 & 80 & 1 \\
\hline $\mathrm{Ni}_{5} / \mathrm{SBA}-15_{1}$ & 54 & 56 & 0.96 & 98 & 88 & 1.03 & 48 & 44 & 0.85 & 97 & 84 & 0.97 \\
\hline $\mathrm{Ni}_{7.5} / \mathrm{SBA}-15_{1}$ & 64 & 57 & 0.9 & 97 & 87 & 1.03 & 46 & 40 & 0.85 & 88 & 80 & 1 \\
\hline $\mathrm{Ni}_{2.5} \mathrm{Ce}_{6} / \mathrm{SBA}-15_{2}$ & 46 & 32 & n.d. & 95 & 78 & n.d. & 32 & 26 & 0.83 & 86 & 82 & 1.02 \\
\hline $\mathrm{Ni}_{5} \mathrm{Ce}_{6} / \mathrm{SBA}-15_{2}$ & 61 & 56 & 0.96 & 98 & 88 & 1.01 & 46 & 49 & 0.85 & 92 & 86 & 1.02 \\
\hline $\mathrm{Ni}_{7.5} \mathrm{Ce}_{6} / \mathrm{SBA}-15_{2}$ & 64 & 60 & 1 & 98 & 86 & 1.09 & 46 & 42 & 0.87 & 94 & 85 & 1.03 \\
\hline $\mathrm{Ni}_{5} / \mathrm{SiO}_{2} *$ & 53 & 47 & n.d. & 85 & 73 & 1.05 & & & & & & \\
\hline
\end{tabular}

* GHSV of $21.1 \mathrm{~L} \cdot \mathrm{g}^{-1} \cdot \mathrm{h}^{-1}$ 
Figure 1: $\mathrm{N}_{2}$ adsorption-desorption isotherms for samples (a) SBA-15, , (b) $\mathrm{Ni}_{7.5} / \mathrm{SBA}-15_{1}$, (c) $\mathrm{SBA}-15_{2},(\mathrm{~d}) \mathrm{Ni}_{0} / \mathrm{SBA}-15_{2}$ and (e) $\mathrm{Ni}_{7.5} \mathrm{Ce}_{6} / \mathrm{SBA}-15_{2}$

Figure 2: SAXS of the calcined SBA- $15_{1}$ and SBA- $15_{2}$ silica

Figure 3: X-ray diffractograms of calcined (a) $\mathrm{Ni}_{2.5} / \mathrm{SBA}-15_{1}$, (b) $\mathrm{Ni}_{7.5} / \mathrm{SBA}-15_{1}$, (c) $\mathrm{Ni}_{2.5} \mathrm{Ce}_{6} / \mathrm{SBA}-15_{2}$ and (d) $\mathrm{Ni}_{7.5} \mathrm{Ce}_{6} / \mathrm{SBA}-15_{2}$

Figure 4: SEM images of calcined samples (a,b) SBA-15 1 , (c) $\mathrm{Ni}_{7.5} / \mathrm{SBA}-15_{1}$ and (d) $\mathrm{Ni}_{7.5} / \mathrm{SBA}-15_{1}$ after catalyst test $\left(800^{\circ} \mathrm{C}\right.$ then $500^{\circ} \mathrm{C}$ for $\left.12 \mathrm{~h}\right)$

Figure 5: Representative TEM micrographs of calcined $\mathrm{Ni}_{\mathrm{x}} / \mathrm{SBA}-15_{1}$ samples showing the highly dispersed $\mathrm{NiO}$ nanoparticles in the SBA-15 pores: observations of isolated particles (a,a') along or (b) perpendicular to the channels, (c,c') particles aligned along the channels and (d) high resolution image of a NiO nanoparticle

Figure 6: TEM micrographs showing (a) external together with internal $\mathrm{NiO}$ nanoparticles in $\mathrm{Ni} \mathrm{i}_{7.5} / \mathrm{SBA}-15_{1}$ and (b) a Cerich grain (atomic ratio $\mathrm{Ce} / \mathrm{Si}=0.14$ ) in $\mathrm{Ni}_{2.5} \mathrm{Ce}_{6} / \mathrm{SBA}-15_{2}$

Figure 7: Variation of the $\left(\mathrm{A}, \mathrm{A}^{\prime}\right) \mathrm{CH}_{4}$ conversions, $\left(\mathrm{B}, \mathrm{B}^{\prime}\right) \mathrm{CO}_{2}$ conversions and $\left(\mathrm{C}, \mathrm{C}^{\prime}\right) \mathrm{H}_{2}$ : $\mathrm{CO}$ molar ratios as a function

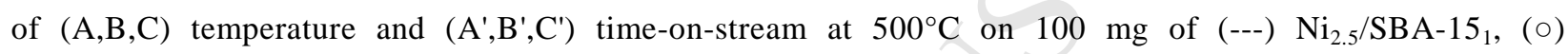
$\mathrm{Ni}_{7.5} / \mathrm{SBA}-15_{1}$ and $(\boldsymbol{\Delta}) \mathrm{Ni}_{7.5} \mathrm{Ce}_{6} / \mathrm{SBA}-15_{2}\left(\mathrm{CH}_{4}: \mathrm{CO}_{2}=1: 1, \mathrm{GHSV}=52.8 \mathrm{~L} \cdot \mathrm{g}^{-1} \cdot \mathrm{h}^{-1}\right)$

Figure 8: (a) temperature profile during reduction and subsequent catalytic/stability testsand comparison of the (b) $\mathrm{CH}_{4}$ conversions and (c) $\mathrm{H}_{2}$ : $\mathrm{CO}$ molar ratios of the $\mathrm{Ni}_{\mathrm{x}} / \mathrm{SBA}-15$ catalysts $(\mathrm{x}=2.5,5$ and 7.5 wt $\%$ ) at steps $\mathrm{A}$ (white columns - at $500^{\circ} \mathrm{C}$ during light-off curve), B (grey columns - after $1 \mathrm{~h}$ at $500^{\circ} \mathrm{C}$ ) and $\mathrm{C}$ (squared columns after $12 \mathrm{~h}$ at $\left.500^{\circ} \mathrm{C}\right)$. The black columns refer to the $\mathrm{Ni}_{\mathrm{x}} \mathrm{Ce}_{6} / \mathrm{SBA}-15_{2}$ samples (after $12 \mathrm{~h}$ at $500^{\circ} \mathrm{C}$ )

Figure 9: Comparison of the conversions of $\mathrm{CH}_{4}\left(\mathrm{~A}, \mathrm{~A}^{\prime}\right)$ and $\mathrm{CO}_{2}\left(\mathrm{~B}, \mathrm{~B}^{\prime}\right)$ at $600^{\circ} \mathrm{C}$ on $\mathrm{Ni} / \mathrm{SBA}-15$ catalysts without $(\mathrm{A}, \mathrm{B})$ and with $\mathrm{Ce}\left(\mathrm{A}^{\prime}, \mathrm{B}^{\prime}\right)$ : this study (black columns, samples with $5 \mathrm{wt} \% \mathrm{Ni}$ ) and bibliographic data (grey columns, catalysts with $\mathrm{Ni}$ contents between 10 and $12 \mathrm{wt} \%)$. * Samples containing zirconia

Figure 10: X-ray diffractograms of spent (a) $\mathrm{Ni}_{7.5} / \mathrm{SBA}-15_{1}$, (b) $\mathrm{Ni}_{2.5} \mathrm{Ce}_{6} / \mathrm{SBA}-15_{2}$ and (c) $\mathrm{Ni}_{7.5} \mathrm{Ce}_{6} / \mathrm{SBA}-15_{2}$

Figure 11: TEM micrographs of the spent catalysts after heating at $800^{\circ} \mathrm{C}$ and $12 \mathrm{~h}$ at $500^{\circ} \mathrm{C}$ under reactants: $\mathrm{Ni}^{0}$ dispersed in SBA-15 grains in (a,b) $\mathrm{Ni}_{5} / \mathrm{SBA}-15_{1}$, and (c) $\mathrm{Ni}_{7.5} \mathrm{Ce}_{6} / \mathrm{SBA}-15_{2}$ (d) high resolution image of a $\mathrm{Ni}^{0}$ nanoparticle and (e) carbon nanotube grown between the support and a nickel nanoparticle 
Figure 1: $\mathrm{N}_{2}$ adsorption-desorption isotherms for samples (a) SBA-15 $5_{1}$, (b) $\mathrm{Ni}_{7.5} / \mathrm{SBA}-15_{1}$, (c) $\mathrm{SBA}-15_{2}$, (d) $\mathrm{Ni}_{0} / \mathrm{SBA}-15_{2}$ and (e) $\mathrm{Ni}_{7.5} \mathrm{Ce}_{6} / \mathrm{SBA}-15_{2}$

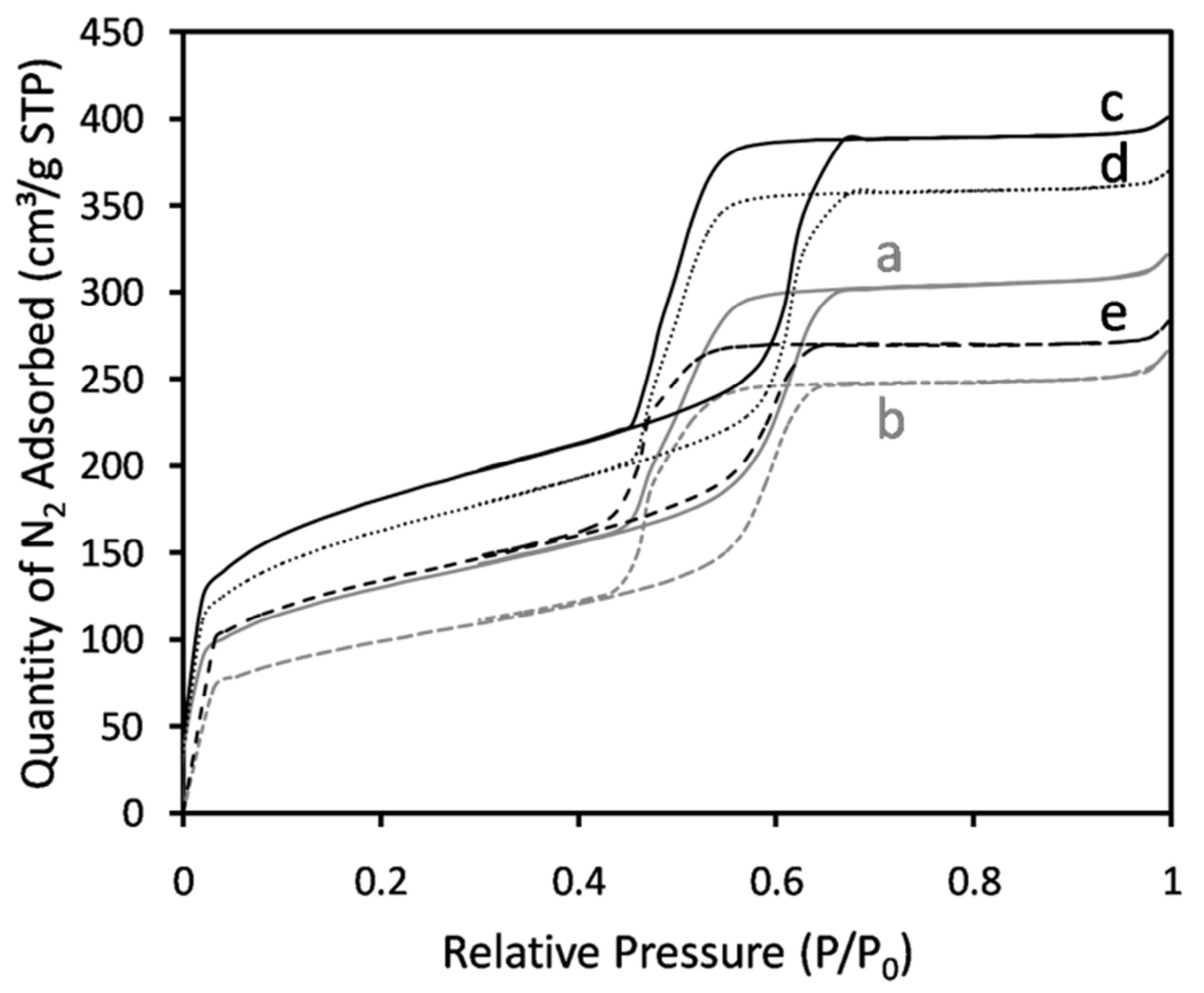




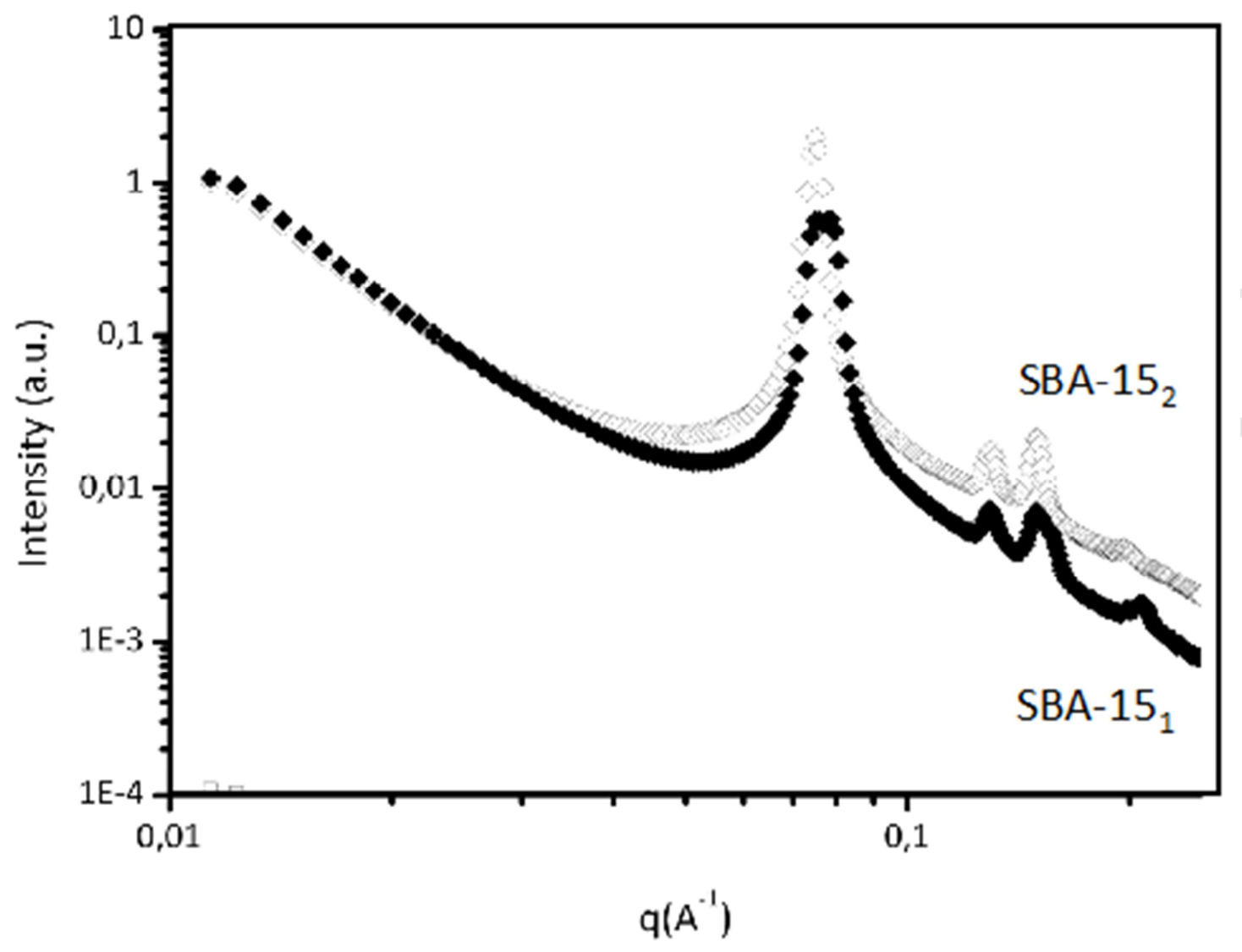


Figure 3: X-ray diffractograms of calcined (a) $\mathrm{Ni}_{2.5} / \mathrm{SBA}-15_{1}$, , (b) $\mathrm{Ni}_{7.5} / \mathrm{SBA}-15_{1}$, (c) $\mathrm{Ni}_{2.5} \mathrm{Ce}_{6} / \mathrm{SBA}-15_{2}$ and (d) $\mathrm{Ni}_{7.5} \mathrm{Ce}_{6} / \mathrm{SBA}^{-}$ $15_{2}$

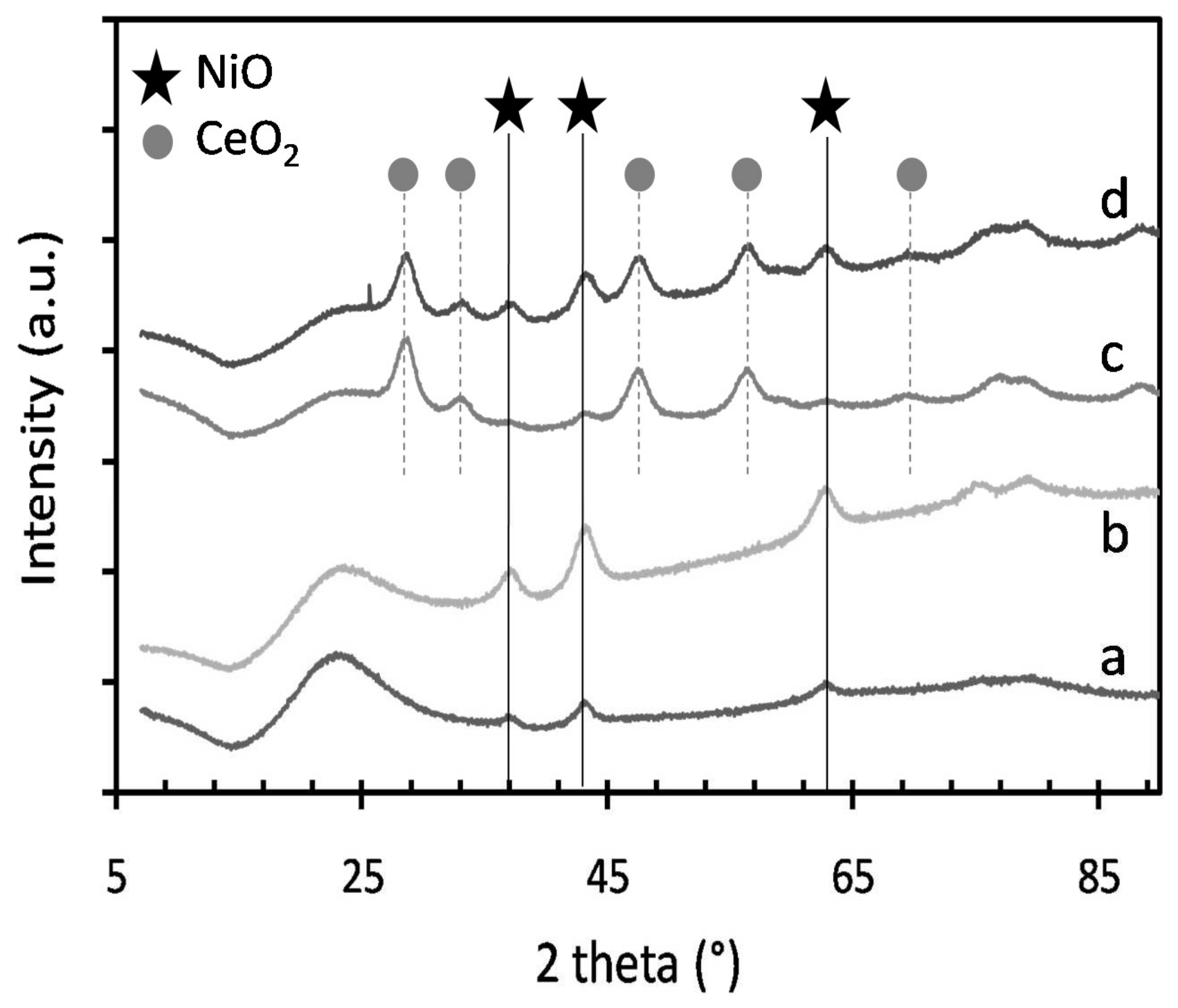


Figure 4: SEM images of calcined samples (a,b) SBA-15, (c) $\mathrm{Ni}_{7.5} / \mathrm{SBA}-15_{1}$ and (d) $\mathrm{Ni}_{7.5} / \mathrm{SBA}-15_{1}$ after catalyst test $\left(800^{\circ} \mathrm{C}\right.$ then $500^{\circ} \mathrm{C}$ for $12 \mathrm{~h}$ )

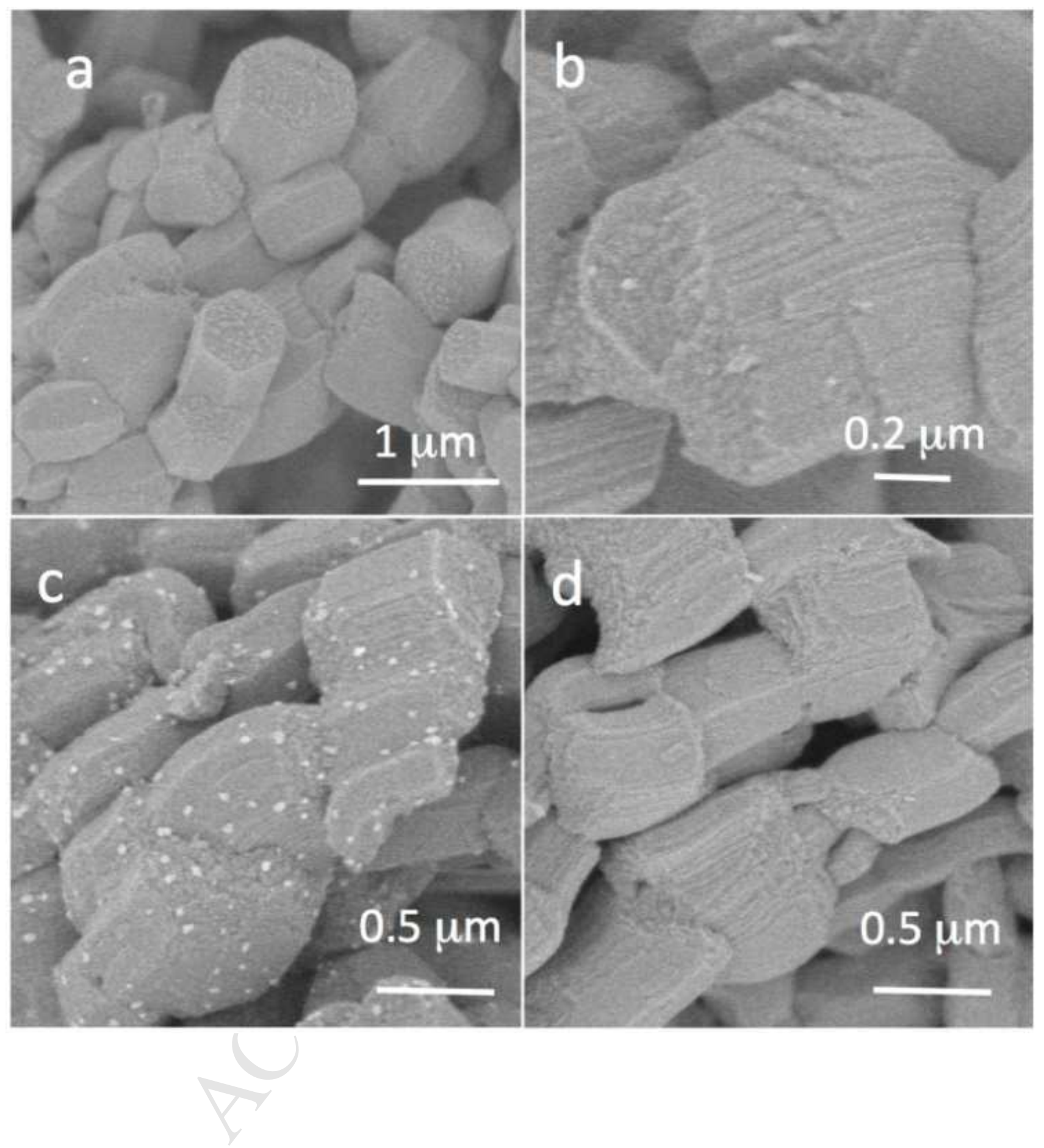


Figure 5: Representative TEM micrographs of calcined $\mathrm{Ni}_{x} / \mathrm{SBA}-15_{1}$ samples showing the highly dispersed $\mathrm{NiO}$ nanoparticles in the SBA-15 pores: observations of isolated particles $\left(\mathrm{a}, \mathrm{a}^{\prime}\right)$ along or (b) perpendicular to the channels, $\left(c, c^{\prime}\right)$ particles aligned along the channels and (d) high resolution image of a $\mathrm{NiO}$ nanoparticle

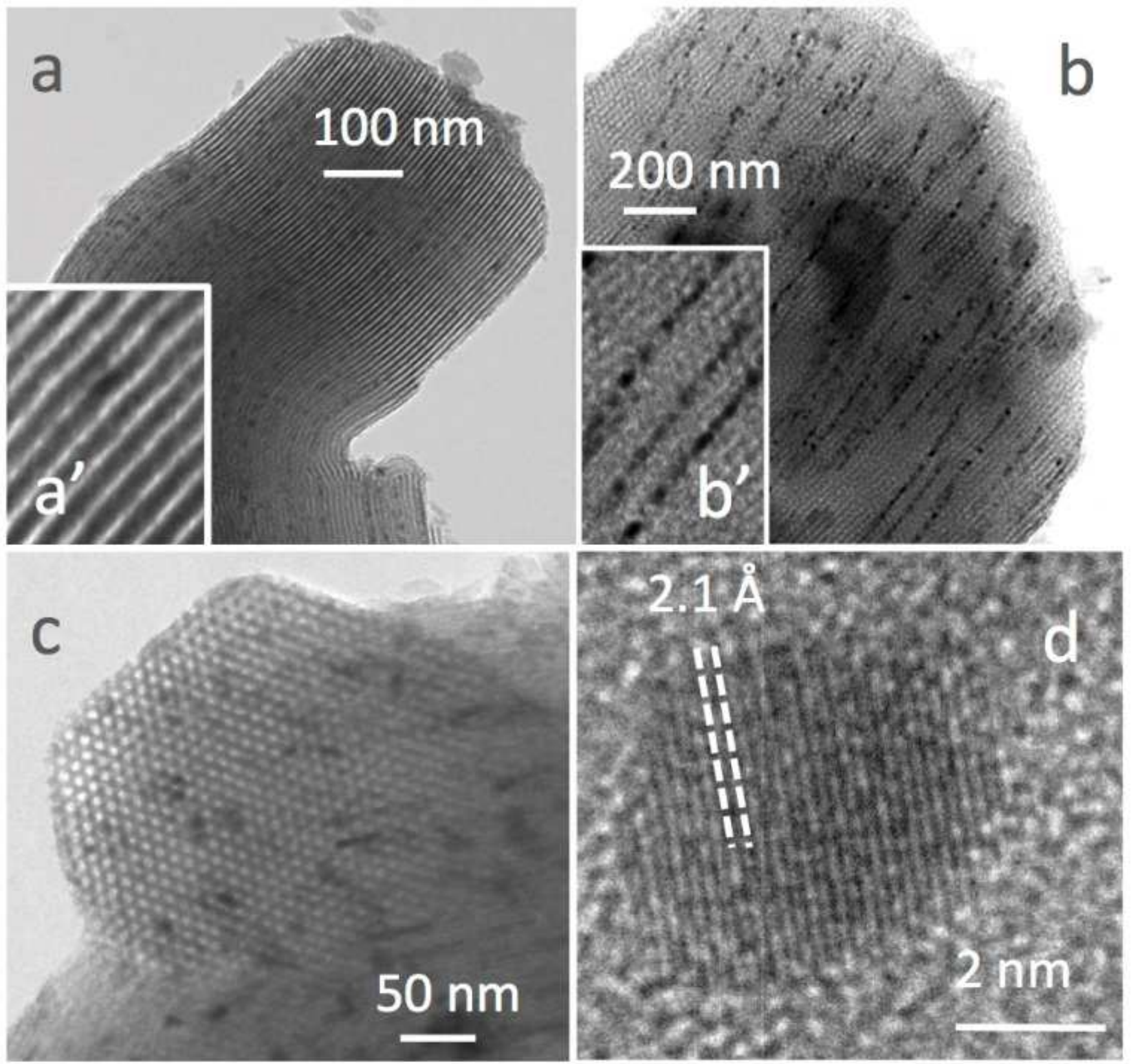


Figure 6: TEM micrographs showing (a) external together with internal $\mathrm{NiO}$ nanoparticles in $\mathrm{Ni}_{7.5} / \mathrm{SBA}-15_{1}$ and (b) a Ce-rich grain (atomic ratio $\mathrm{Ce} / \mathrm{Si}=0.14$ ) in $\mathrm{Ni}_{2.5} \mathrm{Ce}_{6} / \mathrm{SBA}-15_{2}$

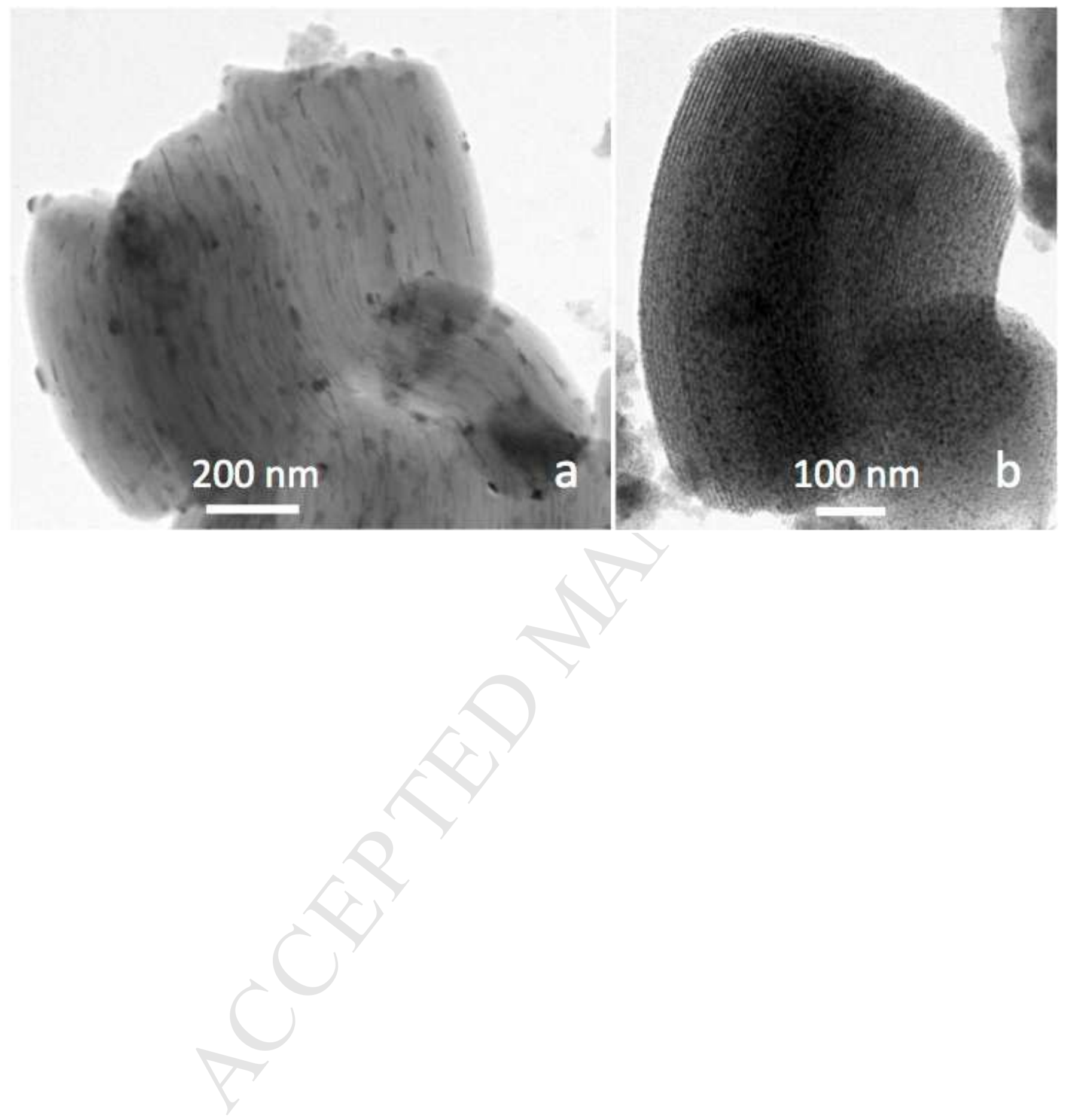


Figure 7: Variation of the $\left(\mathrm{A}, \mathrm{A}^{\prime}\right) \mathrm{CH}_{4}$ conversions, $\left(\mathrm{B}, \mathrm{B}^{\prime}\right) \mathrm{CO}_{2}$ conversions and $\left(\mathrm{C}, \mathrm{C}^{\prime}\right) \mathrm{H}_{2}$ : $\mathrm{CO}$ molar ratios as a function of

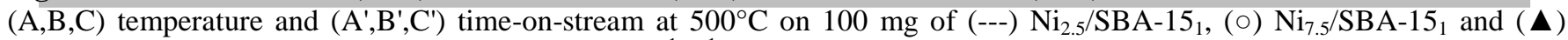
$\mathrm{Ni}_{7.5} \mathrm{Ce}_{6} / \mathrm{SBA}-15_{2}\left(\mathrm{CH}_{4}: \mathrm{CO}_{2}=1: 1, \mathrm{GHSV}=52.8 \mathrm{~L} \cdot \mathrm{g}^{-1} \cdot \mathrm{h}^{-1}\right)$

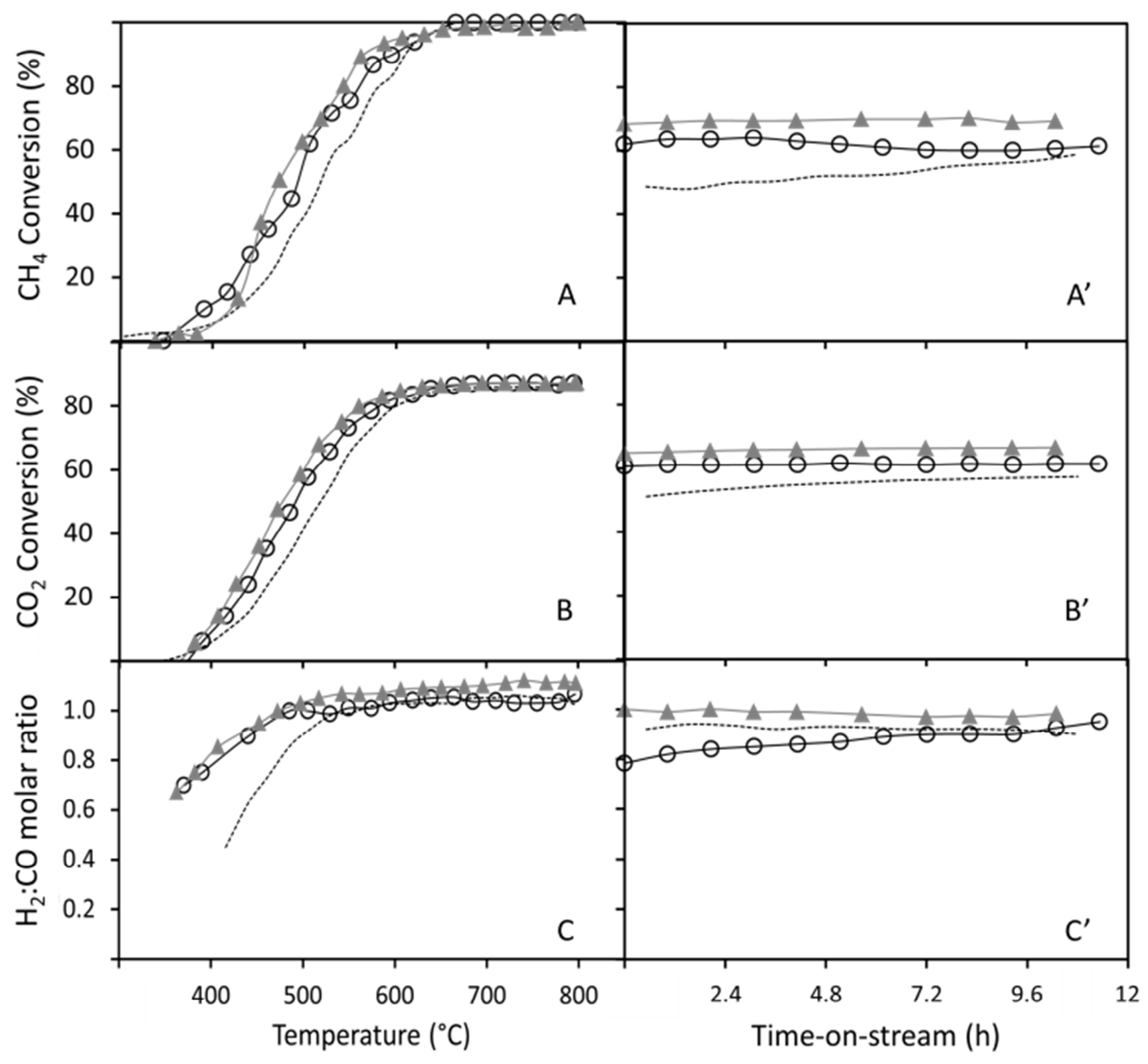


Figure 8: (a) temperature profile during reduction and subsequent catalytic/stability testsand comparison of the (b) $\mathrm{CH}_{4}$ conversions and (c) $\mathrm{H}_{2}$ : $\mathrm{CO}$ molar ratios of the $\mathrm{Ni}_{\mathrm{x}} / \mathrm{SBA}-15$ catalysts $(\mathrm{x}=2.5,5$ and $7.5 \mathrm{wt} \%)$ at steps A (white columns - at $500^{\circ} \mathrm{C}$ during light-off curve), B (grey columns - after $1 \mathrm{~h}$ at $500^{\circ} \mathrm{C}$ ) and $\mathrm{C}$ (squared columns - after $12 \mathrm{~h}$ at $500^{\circ} \mathrm{C}$ ). The black columns refer to the $\mathrm{Ni}_{\mathrm{x}} \mathrm{Ce}_{6} / \mathrm{SBA}-15_{2}$ samples (after $12 \mathrm{~h}$ at $500^{\circ} \mathrm{C}$ )
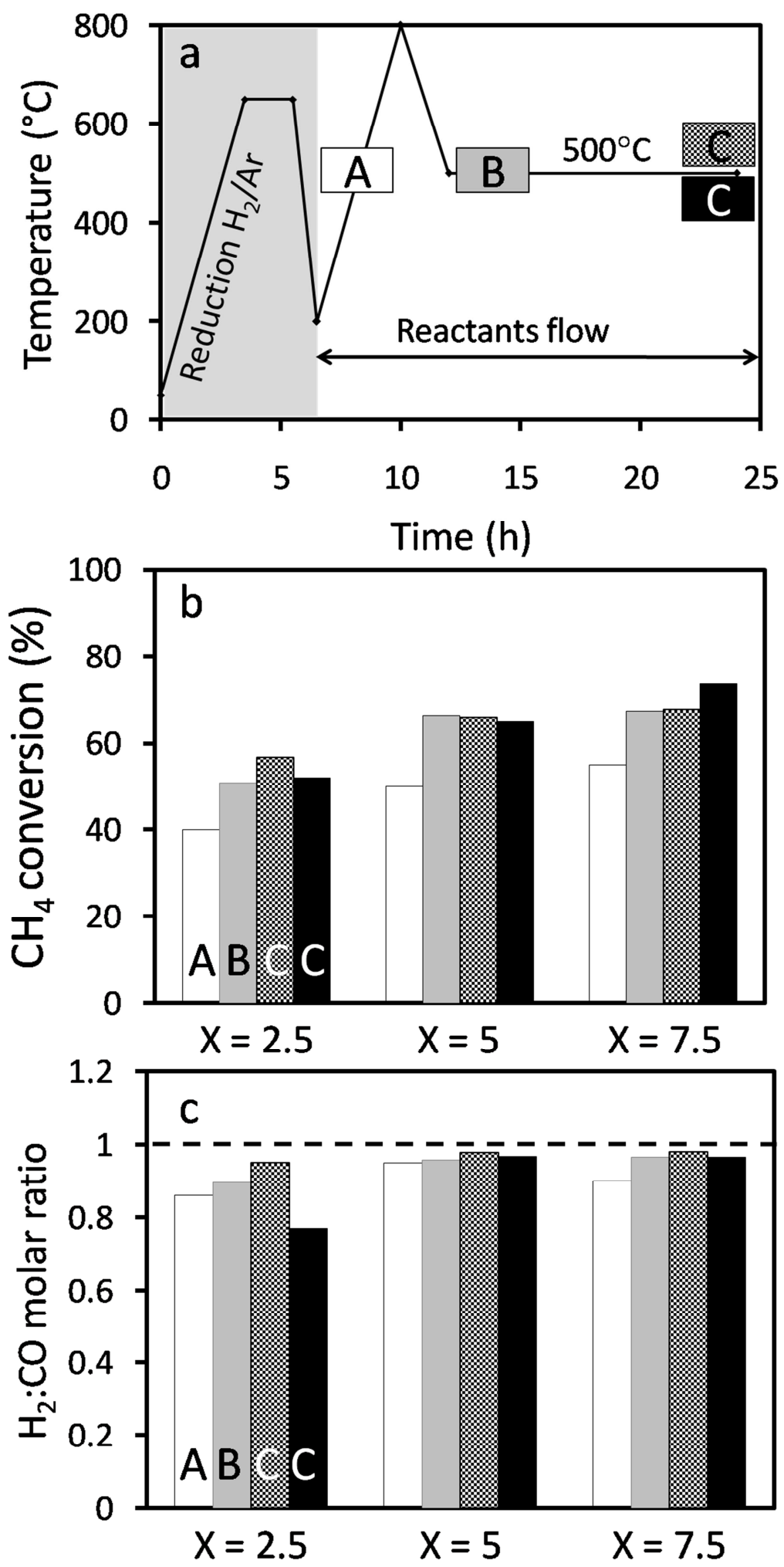
Figure 9: Comparison of the conversions of $\mathrm{CH}_{4}\left(\mathrm{~A}, \mathrm{~A}^{\prime}\right)$ and $\mathrm{CO}_{2}\left(\mathrm{~B}^{\prime}, \mathrm{B}^{\prime}\right)$ at $600^{\circ} \mathrm{C}$ on Ni/SBA-15 catalysts without $(\mathrm{A}, \mathrm{B})$ and with $\mathrm{Ce}\left(\mathrm{A}^{\prime}, \mathrm{B}^{\prime}\right)$ : this study (black columns, samples with $5 \mathrm{wt} \% \mathrm{Ni}$ ) and bibliographic data (grey columns, catalysts with Ni contents between 10 and $12 \mathrm{wt} \%)$ * Samples containing zirconia

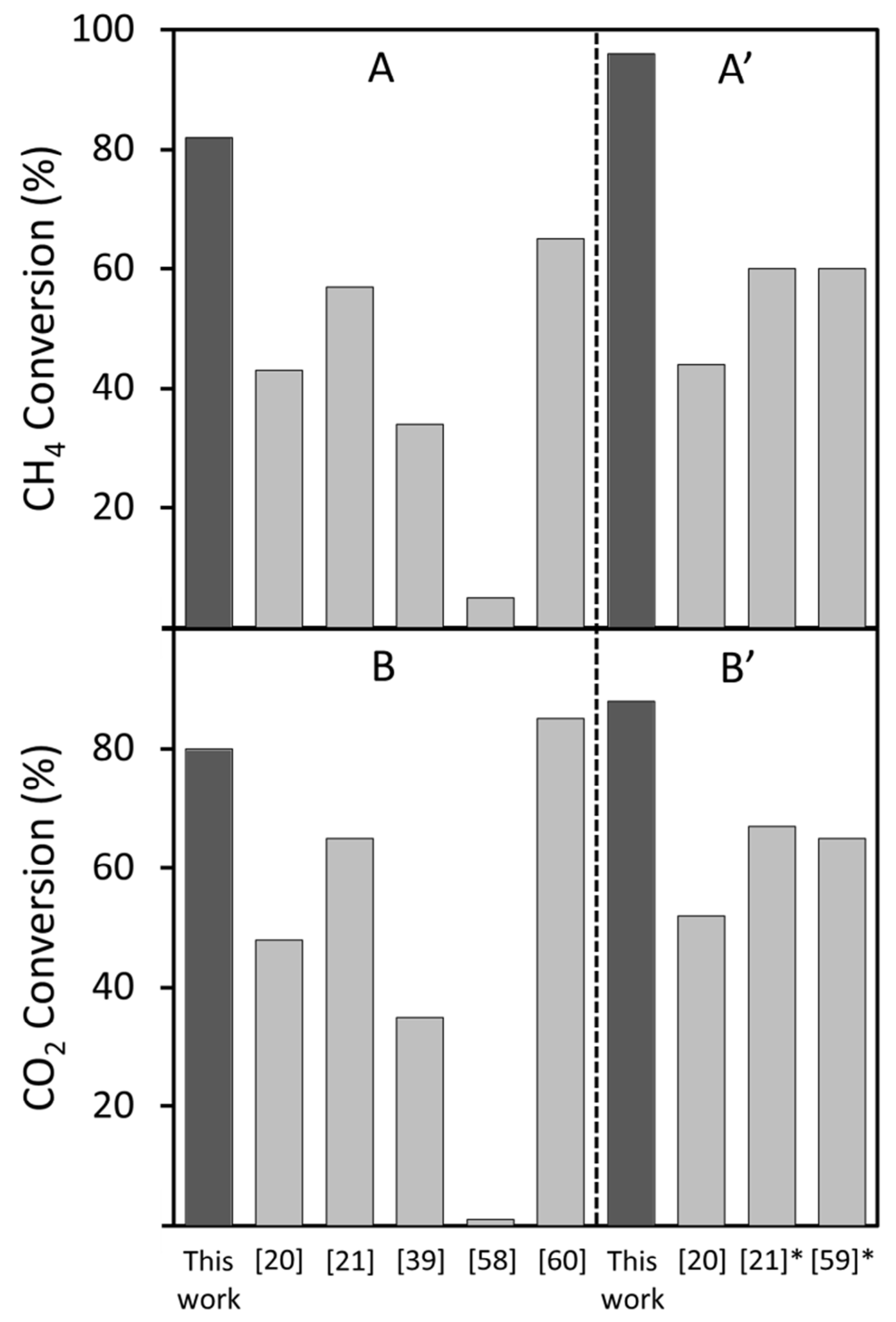




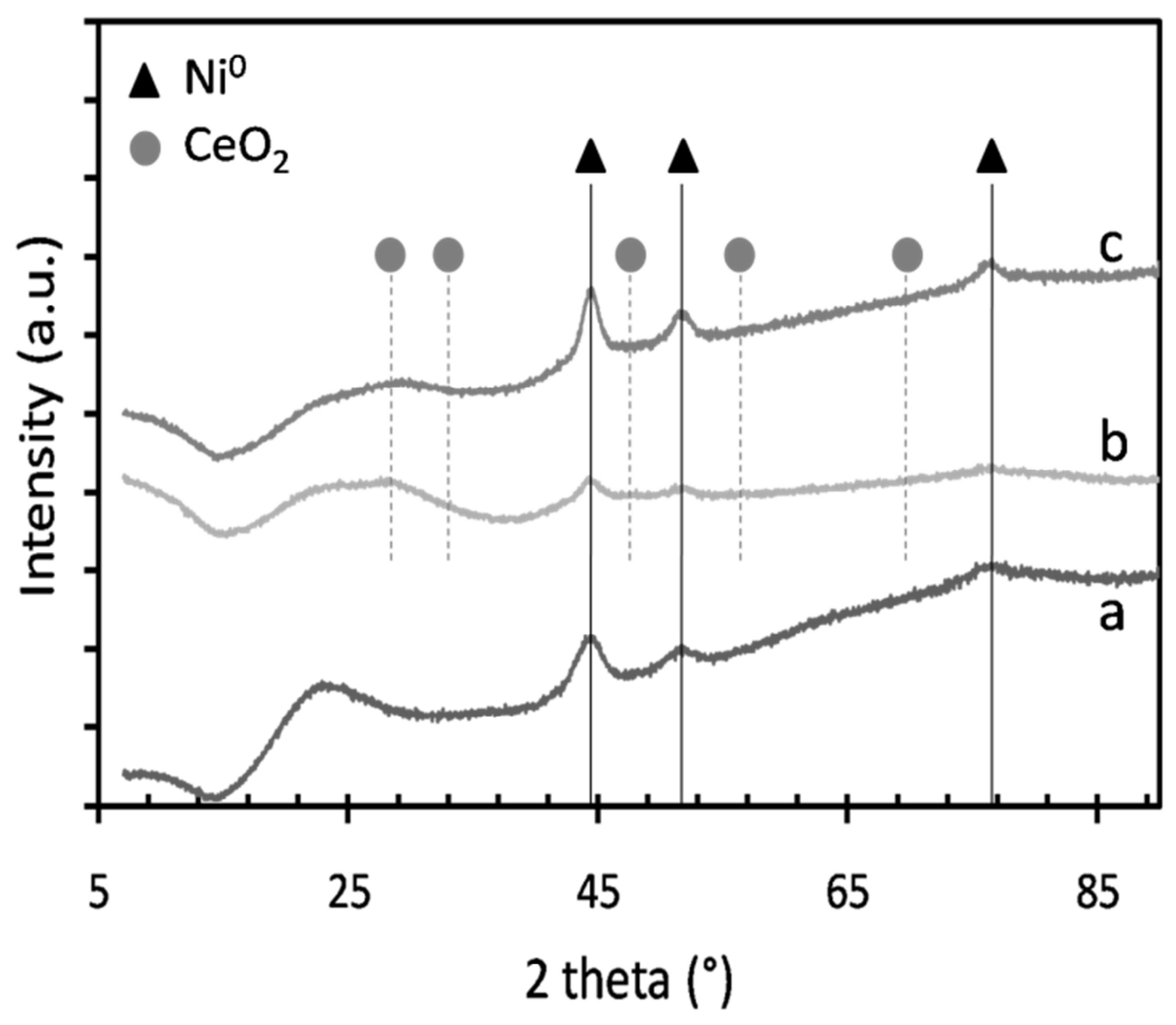


Figure 11: TEM micrographs of the spent catalysts after heating at $800^{\circ} \mathrm{C}$ and $12 \mathrm{~h}$ at $500^{\circ} \mathrm{C}$ under reactants: $\mathrm{Ni}^{0}$ dispersed in SBA-15 grains in $(\mathrm{a}, \mathrm{b}) \mathrm{Ni}_{5} / \mathrm{SBA}-15_{1}$, and (c) $\mathrm{Ni}_{7.5} \mathrm{Ce}_{6} / \mathrm{SBA}-15_{2}$ (d) high resolution image of a $\mathrm{Ni}^{0}$ nanoparticle and (e) carbon nanotube grown between the support and a nickel nanoparticle

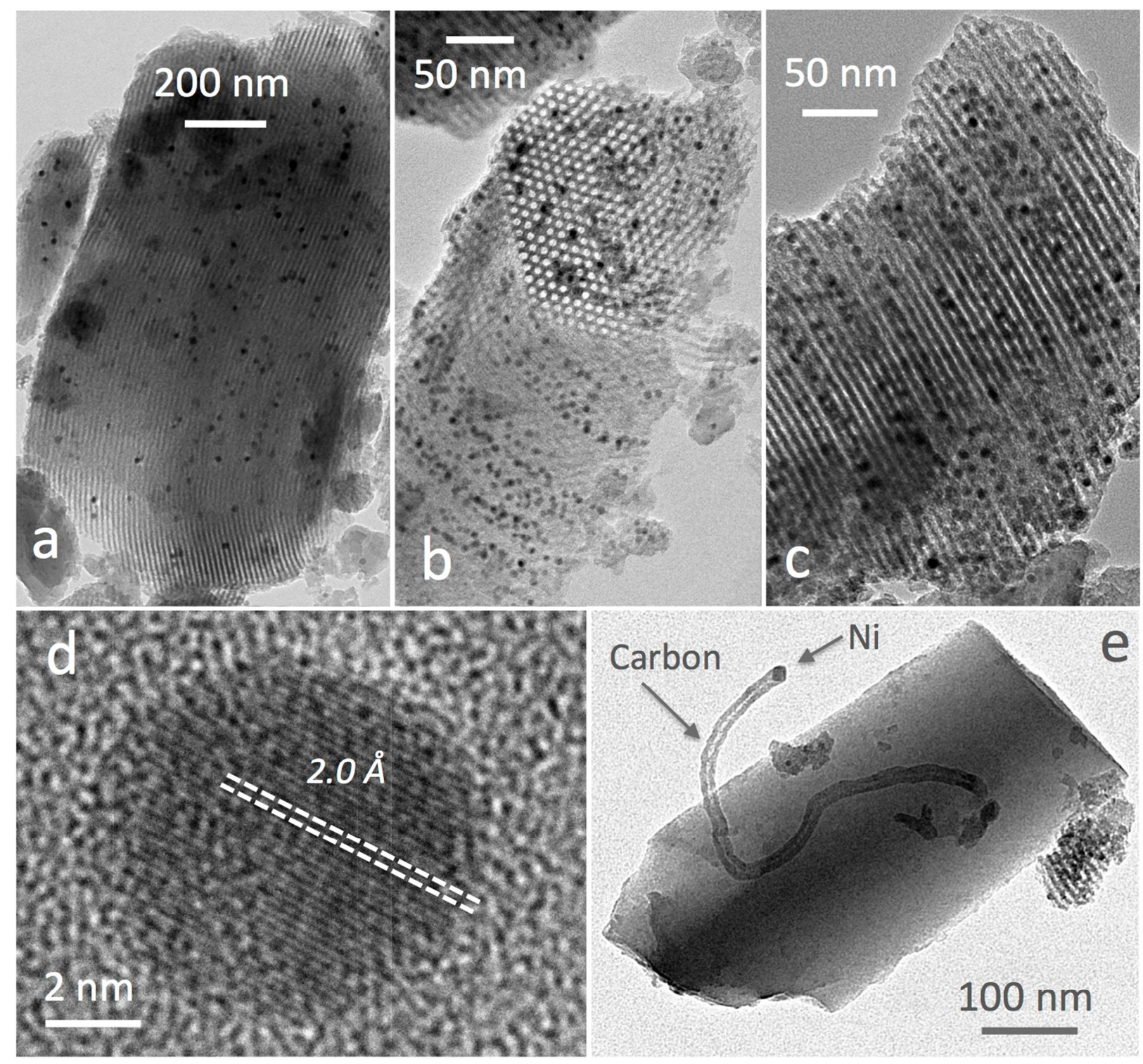




\section{Highlights}

- High Ni dispersion was obtained in the pores of SBA-15 by a two solvent deposition method.

- Stabilization of the metal nanoparticles along the channels, in a confined environment, inhibits nickel sintering and coke formation.

- The obtained Ni/SBA-15 are highly active and selective in dry reforming of methane, with almost $100 \% \mathrm{CH}_{4}$ and $\mathrm{CO}_{2}$ conversion at $600^{\circ} \mathrm{C}$. 